Portland State University

PDXScholar

5-17-1995

\title{
Effect of Ototoxic Drugs on the Amphibian Auditory System: Injection of Gentamicin Sulfate into Anuran Otic Capsules and Recovery of Thresholds
}

Michael Patrick Brown

Portland State University

Follow this and additional works at: https://pdxscholar.library.pdx.edu/open_access_etds

Part of the Biology Commons

Let us know how access to this document benefits you.

\section{Recommended Citation}

Brown, Michael Patrick, "Effect of Ototoxic Drugs on the Amphibian Auditory System: Injection of Gentamicin Sulfate into Anuran Otic Capsules and Recovery of Thresholds" (1995). Dissertations and Theses. Paper 4858.

https://doi.org/10.15760/etd.6734

This Thesis is brought to you for free and open access. It has been accepted for inclusion in Dissertations and Theses by an authorized administrator of PDXScholar. Please contact us if we can make this document more accessible: pdxscholar@pdx.edu. 


\section{THESIS APPROVAI}

The abstract and thesis of Michael Patrick Brown for the Master of Science in Biology were presented on May 17, 1995 and accepted by the thesis committee and the department.

\section{COMMITTEE APPROVALS:}

DEPARTMENT APPROVAL:

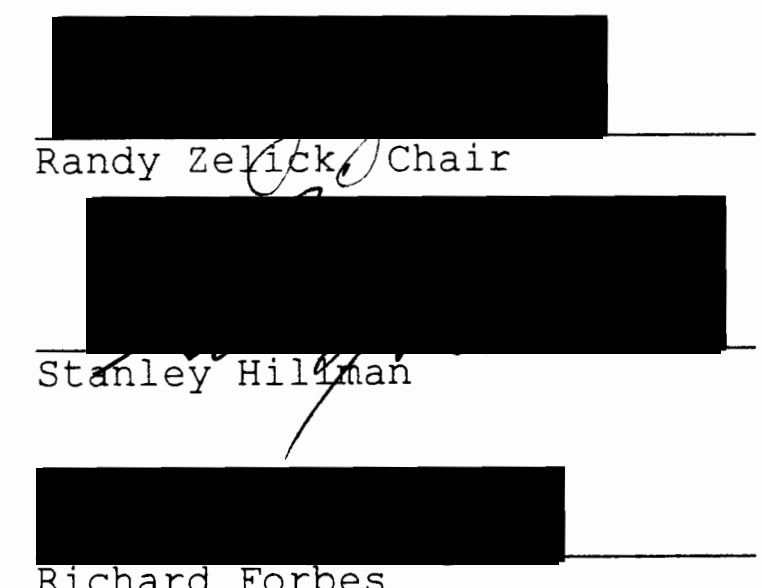

Richard Forbes

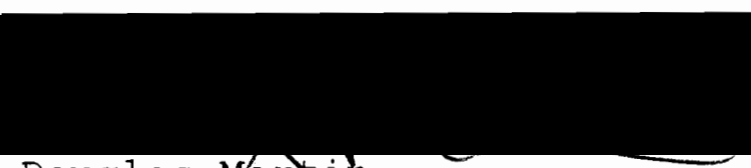

Douglas Mar in

Representative of the Office of Graduate Studies

ACCEPTED FOR PORTLAND STATE UNIVERSITY BY THE LIBRARY

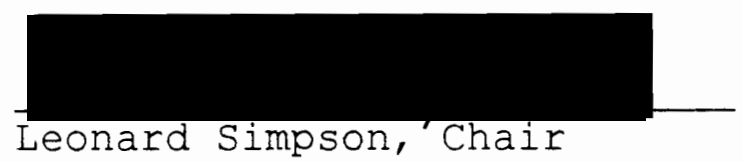

Department of Biology

\section{$* *$
ACC
by}

Department of Biology 


\section{ABSTRACT}

An abstract of the thesis of Michael Patrick Brown for the Master of Science in Biology presented May 17, 1995.

Title: Effect of Ototoxic Drugs on the Amphibian Auditory System: Injection of Gentamicin Sulfate into Anuran Otic Capsules and Recovery of Thresholds

Hair cell trauma from aminoglycosides, which may lead to permanent loss of hair cells in mammals, was studied physiologically in frogs by measuring an auditory evoked potential (AEP) in Rana pipiens. The AEP was evaluated in order to measure threshold shift (TS) and recovery from TS after the administration of the aminoglycoside antibiotic, gentamicin. To obtain an AEP, chronic electrodes were implanted into the cranium near the cochlear nucleus. The frogs were then exposed to frequency-specific narrow band "clicks" which included a single period $1 \mathrm{kHz}$ sinewave, and a computer synthesized high frequency and low frequency click. Amphibians have two hearing organs, the amphibian and basilar papillae, sensitive to low (150-1500) and high (1500-2000) frequencies, respectively. The low (AP) and 
high (BP) frequency clicks were created to stimulate specifically the corresponding papillae. After normal thresholds were recorded for each frog, gentamicin sulfate, $200 \mu \mathrm{M}, 300 \mu \mathrm{M}$, or $400 \mu \mathrm{M}$, was injected bilaterally into the otic capsules. Thresholds were recorded until the TS had disappeared, allowing the threshold recovery period to be measured. The injections of $200 \mu \mathrm{M}$ yielded a $10 \mathrm{~dB}$ change in one animal and no change in two others. The injection of $300 \mu \mathrm{M}$ into 10 frogs and $400 \mu \mathrm{M}$ into 20 frogs yielded at least a $10 \mathrm{~dB}$ change in $60 \%$ and $93 \%$ of the frogs, respectively, with the concentration of $400 \mu \mathrm{M}$ producing threshold shifts of $20 \mathrm{~dB}$. Thus, the threshold shifts were dose-dependent. Recovery times varied between six and fourteen days. No apparent differences between thresholds for the high frequency click, low frequency click and sinewave clicks were observed. 


\title{
EFFECT OF OTOTOXIC DRUGS ON THE AMPHIBIAN AUDITORY SYSTEM: INJECTION OF GENTAMICIN SULFATE INTO ANURAN OTIC CAPSULES AND RECOVERY OF THRESHOLDS
}

by

MICHAEL PATRICK BROWN

A thesis submitted in partial fulfillment of the requirements for the degree of

MASTER OF SCIENCE

in

BIOLOGY

\author{
Portland State University \\ 1995
}




\section{Acknowledgements}

I would like first to thank my mother and father for all of their love and support. I must also thank Dr. Randy Zelick for his help and support. All the members of the lab, especially Cathie Cookus and Mark Parker, assisted tremendously in this project. Thank you to Jim Stapleton who developed the clicks and always assisted when possible. Thank you to Richard Baird and Nancy Schuff of the R.S. Dow Neurological Sciences Institute for their valuable assistance and advice. Thank you also to David Laszlo for his assistance with the data analysis and for being a great friend. A special thanks to Debbie Duffield for all of her assistance and for always believing in me. 


\section{Introduction}

In our quest to relieve the pain and suffering of people through the use of drugs, even though the objective may be reached, unexpected repercussions may occur. It has long been known that treatment with one class of antibiotic, the aminoglycosides, can cause damage to the auditory system (Girod and Rubel, 1991). It has been estimated that in the United States hearing impairment, frequently irreversible, occurs in as many as 5\% of patients who have received aminoglycosidic treatment (Kroese et al., 1989). Despite this negative consequence, the particular effectiveness of aminoglycosides supports their continued use. For example, aminoglycoside antibiotics are used primarily in the treatment of meningitis and other serious infections (Arritola, 1995; Duff, 1992).

Hair cells of the inner ear transduce motion into neural signals for further nervous system processing and are the elements apparently damaged following chemical or acoustic trauma (Lefebvre et. al., 1993; Lippe et al., 1991; Pugliano et al., 1993a). In most studies, the 
amount of hair cell damage is assessed by sacrificing the animal at specific periods post-treatment and, utilizing electron microscopy, viewing hair cells directly (Baird et al., 1993; Forge et al., 1993; Raphael, 1993; Cotanche and Lee, 1994). This method provides a direct correlation between the amount of trauma induced and the number of hair cells damaged. A few studies have examined physiological measures of damage, but no studies in amphibians have measured physiological changes in response to ototoxic drugs (Baird et al., 1993; Kroese et al., 1989).

In this study, I examine the effects of one aminoglycoside antibiotic, gentamicin, on the hearing of the anuran amphibian, Rana pipiens. Unlike several other studies, rather than systemic injection, the aminoglycoside was injected bilaterally into the otic capsules (Baird et al, 1993; Hashino et al., 1992; Lombarte et al., 1993). The otic capsule is a bony region of the head containing the auditory papillae. The drug's effect was monitored utilizing an auditory brainstem recording ( $A B R$ ) method in which electrodes were implanted near the brainstem to detect volume-conducted potentials from the VIII cranial nerve and ascending auditory nerve 
nuclei. Because the electrodes were implanted chronically, this method allows measurement of frog hearing threshold, in most cases, up to five weeks. Depending on the concentration, the treatments resulted in temporary threshold shifts (TTS), with a return to normal threshold within 7-14 days.

Frogs possess two hearing organs in each ear, the amphibian papilla (AP) and basilar papilla (BP) (Lewis et al., 1992). Even though there are actually eight sensory organs with hair cells, only the AP and BP respond to acoustic stimuli. The other six are vestibular organs and include three semicircular canals, utricle, saccule, and lagena (Wilczynski and Capranica, 1984). The AP is unique to amphibians and is generally larger than the BP. The AP is most sensitive to low frequencies and the BP to higher frequencies (reviewed in Wilczynski and Capranica, 1984). Because the AP and $\mathrm{BP}$ are two separate organs, it is possible that aminoglycosides affect each organ differently. For example, the high frequencies may be affected more than the low frequencies. This is the first study to attempt to stimulate the AP and BP separately using an $A B R$ technique. This was accomplished using 
computer generated high frequency and low frequency clicks. 


\section{Literature Review}

\section{Hair Cells:}

Vertebrates have developed efficient neural sensory systems for the processing of sound. One feature common to these systems is the hair cell. When appropriately stimulated, this mechanoreceptive sensory cell converts changes in sound pressure to electrical signals. These neural signals are then transmitted to the higher centers of the brain for processing. In mammals, the hair cells are arranged on the cochlea such that they are "tuned" to specific frequencies. This phenomenon is referred to as tonotopic organization and is preserved in the neural pathway to the brain. However, tonotopy is not present in all auditory organs of different species (Cotanche et al., 1994; Corwin and Warchol, 1991).

Somewhat independent of tonotopic organization is the orientation of the hair cells. Each hair cell body has a base on which there is a bundle of stereovilli. The stereovilli determine the structural and functional characteristics of the bundle (Corwin and Warchol, 1991). In mammals, there exist four highly ordered rows of hair cells in the cochlea. However, not all animals have a 
cochlea with this arrangement. For example, birds, reptiles and amphibians lack cochleas (Corwin and Warchol, 1991; Corwin et al, 1993). Instead, a simpler papilla is found in place of the more complex cochlear organ of Corti and basilar membrane. Hair cells often vary in their orientation on a papilla and may appear to be randomly dispersed. In fish, hair cells are arranged in various ordered configurations in the sacculus (Lombarte et al., 1993; Presson et al., 1995; Weisleder and Zakon, 1995). Birds posses a papilla with ordered, tuned hair cells which are sensitive to specific frequencies (Corwin and Warchol, 1991).

In most frog species, the hair cells of the AP are distributed along a long " $\mathrm{S}$ "-shaped organ. The hair cells themselves possess a bundle of stereovilli with a longer kinocilium at one end of the bundle. The AP has an ordered arrangement of hair cells (Schmitz et al., 1992). However, the specific orientation of the hair cells may vary along different regions of the papilla (Lewis et al, 1992). The hair cells of the BP are arranged in a semicircle, and the kinocilium on each hair cell, is located on the side of the bundle with the shortest stereovilli. The BP hair cells all have an identical 
orientation (Wilczynski and Capranica, 1983). The AP supports a traveling wave and neural tonotopy. However, tonotopy is not a characteristic of the BP (Corwin and Warchol, 1991; Hillery and Narins, 1984).

Hair cells may be damaged by two mechanisms, acoustic overstimulation and ototoxicity, as caused by drug treatments (Abdouh et al., 1993; Aran et al., 1995; Duckert and Rubel, 1993a). Acoustic overstimulation caused by noise exposure is a universal concern today because of exposure to loud music and machinery noise. However, ototoxicity caused by drug treatments is fast becoming a major problem faced by the medical community. The loss of hair cells by this means is responsible for hearing and balance deficits that affect millions of people (Mandell et al., 1990). Problems associated with vestibular toxicity include vertigo, disequilibrium, lightheadedness, nausea, and vomiting. Ototoxicity can lead to tinnitis (ringing) and temporary or permanent hearing loss (Smith and Swenson, 1990; Tsue et al., 1994). It has been estimated that approximately 5\% of the population has hearing impairment as the result of the destruction of hair cells (Kroese and Bercken, 1982). 


\section{Aminoglycosides:}

Many drugs sold today may cause ototoxicity as a side effect (Duckert and Rubel, 1993a). Aminoglycosides fall into this category. Unfortunately, sometimes the need for the medication outweighs the risk of possible side effects. Aminoglycoside antibiotics are the drugs of choice for bacterial meningitis and many other serious infections (Duff, 1992; Ernst and Zenner, 1992). Their main target is aerobic gram-negative bacilli, namely Pseudomonas species and virtually all strains of Streptococcus faecalis (Mandell et al, 1990). Besides nephrotoxicity and neuromuscular paralysis, all aminoglycosides are capable of causing ototoxicity which can lead to permanent hearing loss. There are several types of aminoglycosides which may affect hair cell organs differently. The mammalian vestibular system is primarily susceptible to damage by streptomycin and gentamicin, while amikacin, kanamycin, and neomycin primarily affect the cochlear system (Mandell et al., 1990; Wanke and Moore, 1991). In fact, approximately 25\% of the patients under streptomycin treatment experience vertigo or other vestibular disturbances (Smith and Swenson, 1990). 
On the molecular level, aminoglycoside antibiotics contain two or more aminosugars linked by glycosidic bonds to an aminocyclitol ring. The primary difference between the aminoglycosides is in the nature of the hydroxyl and aminosugar groups that are linked to the central aminocyclitol ring (Mandell et al., 1990). In general, the mechanism of action is the inhibition of protein synthesis by binding directly to the $30 \mathrm{~s}$ ribosommal subunit (Arritola, 1995). This kills the bacteria. The exact mechanism of action on the sensory hair cells is still under investigation, but it appears that the sensory hair cell membrane is compromised (Denk et al., 1992). In many instances following aminoglycoside treatment, morphological assessment reveals that hair cells are actually fused to one another (Arritola, 1995).

Aminoglycosides can inhibit phosphoinositide metabolism in cell membranes and can interfere with the calcium binding sites in the membranes (Stiffler, 1993). The interference with the calcium dependent mechanisms can effect the actin/myosin interaction and can result in the shortening of the outer hair cells (OHCs) of the mammalian cochlea (Cecola and Bobbin, 1992; Harada et al., 1994). Calcium plays an integral role in hair cell metabolism, 
cell shape, and cell excitability (Slepecky et al., 1993). Research on mice suggests a reduction in a calcium-binding protein, s-100, resulting in a disruption of calcium metabolism (Tahara et al., 1995). Still further research suggests that formation of free radicals by aminoglycosides leads to the destruction of hair cells (Clerici et al., 1995; Meiteles and Rapheal, 1994; Priuska and Schacht, 1995).

It is known that the half-life of aminoglycosides is approximately five to six times longer in the otic fluid than in the circulating plasma (Arritola, 1995). Immunohistochemical methods have demonstrated that aminoglycosides can specifically penetrate into the sensory cells (Aran et al., 1993). However, it is not well understood how the drugs are initially absorbed into the endolymph and perilymph (Walker et al., 1990). It is conceivable that an over-accumulation within the stereovilli causes the blockage of the calcium binding sites (Nakagawa et al., 1992; Walker et al., 1990). Imamura and Adams, (1995) found that after systemic and local injection, aminoglycosides accumulated in several auditory and vestibular hair cells often causing 
disruption of cellular components such as calmodulin, S100, and sodium-potassium ATPase.

Decreased carbohydrate uptake due to the presence of aminoglycosides may be another cause of hearing loss. It has been suggested that certain carbohydrates are important in anchoring stereovilli tip links of hair cells and as well as anchoring stereovilli to the overlaying tectorial membrane (Epstein and Cotanche, 1995; Plinkert et al., 1992; Tilney et al., 1992). If aminoglycosides disrupted the uptake of carbohydrates, normal cell functioning would be compromised. Of course, one must also realize that different aminoglycosides could each produce different results and different levels of severity.

\section{Current Research:}

In some animals, hair cells possess the ability to regenerate after auditory trauma. The regenerative capabilities of amphibians are well known. Unlike the hair cells of amphibians, for many years it was believed that the hair cells of both the avian and mammalian cochlea did not regenerate. This was first challenged by several studies indicating the avian cochlea is capable of 
regenerating new sensory cells (Chen et. al., 1993;

Cotanche and Lee, 1994). Recently, it has been

demonstrated that under certain conditions, mammalian sensory epithelium may also have the ability to recover structurally and functionally (Cotanche et al., 1994).

Although not as prevalent as research on amphibians and birds, research has also been focused on fish (Rubel et al., 1991; Corwin et al., 1991). However, like amphibians, teleost fish possess a continual postembryonic production of sensory hair cells (Weisleder and Zakon, 1995; Presson et al., 1995; Corwin et al., 1991). In fact, a possible correlation has been discovered between the number of hair cells damaged and the size of the fish. Lombarte et al. (1993) state "The time course for damage was longer in larger fish, but the recovery of the ciliary bundles appeared to be complete about 10 days after the maximal damage was seen in both the smaller and larger fish." The drugs were injected intramuscularly and the experimental animals sacrificed post-injection to examine the condition of the hair cells.

In birds, there is evidence to suggest that hair cells can regenerate in chicks but not in the adult chicken. This could result from the fact that the chick 
tissue still contains proliferating cells. The hair cells, the production of which normally occurs in embryogenesis, have been found to undergo mitosis after acoustic or ototoxic trauma (Raphael, 1993; Oesterle et al., 1993; Stone and Cotanche, 1992). Many of the studies on avian hair cells have used pure tones as the source of trauma while others have used various aminoglycosides as the source of trauma (Adler et al., 1992; Li et al., 1994; Lomax et al., 1995; Pugliano et al., 1993b). Aminoglycosides commonly used experimentally include gentamicin, streptomycin, and kanamycin (Duckert and Rubel, 1993b; Weisleder and Rubel, 1993; Hashino et al., 1992). Finally, Lippe et al. (1995) reported that aminoglycoside toxicity not only damages the hair cells but also causes a loss of spiral ganglion cells, i.e., the auditory nerve ganglion. Loss of spiral ganglion cells could compromise hair cell recovery (Lippe et al., 1995).

Most of the research on avian hair cells includes the harvesting of hair cells and microscopic examination postexposure (Duckert and Rubel, 1993b; Stone et al., 1995). Furthermore, in most instances, the drugs being tested were either injected into the animal or fed to the animal. 
Both of these methods may include a degree of uncertainty as to exactly how much of the drug is damaging the hair cells. Very few studies on birds examined threshold shifts using $A B R$ techniques (Lou et al., 1994). Most of these use several different stimuli of different frequencies (Trautwein, 1995). For example, in order to damage the hair cells, chicks were exposed to pure tones. In one particular study (Saunders et al., 1993), chicks were anesthetized, tracheotomized, and hearing examined using $A B R$ methods. Electrodes were inserted near the brainstem and the animals stimulated with tones of various frequencies. In another study using $A B R$ techniques and noise dosing, it was found that after fourteen days, the thresholds returned to their pre-exposure levels (Umemoto et al., 1993). An interesting study involved the training of adult quails to peck when tones were detected. Recovery times were then examined after exposures to pure tone stimuli (Niemiec et al., 1995).

In mammals, research has been focused on monkeys, pigs, chinchillas and rats among others (Alles and Pye, 1993; Ankerstjerne et al., 1995; Canlon et al., 1988; Quint et al., 1995). Limited research has also been conducted on human subjects. Recently, numerous studies 
have focused on the proliferation of sensory hair cells in mammals since hair cell regeneration in mammals had been thought to be not possible. However, this has since been proved to be incorrect (Abdouh et al., 1993; Cotanche and Lee, 1994; Forge et al., 1993; Lefebvre et al., 1993; Warchol et al., 1993). Normally, the production of hair cells is completed at the end of the first half of the gestation period. However, repair of stereovilli after damage suggests the capability for replacement of hair cells in the mammalian cochlea (Lefebvre et al., 1993). Some of the initial research supporting the regeneration of mammalian hair cells was conducted on rats. However, research on guinea pigs and chinchillas is now very common (Pye and Collins, 1991). Lefebvre (1993) found that retinoic acid has the capability to stimulate the regeneration of hair cells in rats following damage to the hair cells by aminoglycoside drug treatment. Other studies have also found a correlation between retinoic acid and hair cell production (Kelley et al., 1993). Few studies examine drug effects or noise dosing effects using ABR methods (Hiel et al., 1993; Ma, 1990). As for birds, much of the research on mammals involves the sacrificing of the animal in order to examine the hair cells 
microscopically (Lefebvre, et al., 1993; Meza-Ruiz et al., 1995; Quint et al., 1995).

Research on humans has been limited to subjects receiving drug treatments (Cheung et al., 1990). Of course, neither examination of the hair cells nor singleunit recording is feasible in humans so, $A B R$ methods are utilized. Throughout the drug course for patients receiving aminoglycosidic treatment, $A B R$ data was collected for early detection of ototoxicity (Fausti et al., 1992; Salonna et al., 1992). This study not only provides valuable data for humans, but can also be used to help determine safe therapeutic levels before the ototoxicity or nephrotoxicity occur (Shrimpton et al., 1993).

\section{Anatomy of the Frog:}

Even though there are similarities between the mammalian and anuran ear, there are major external ear and inner ear differences. While anuran amphibians do not have a pinna, most possess tympanic membranes contiguous with the skin. Rather than three middle ear ossicles, there is usually a single columella which mechanically links the tympanum to the inner ear fluid space. Anurans 
also have two auditory organs, the amphibian papilla (AP) and the basilar papilla (BP) (Wilczynski and Capranica, 1984). The AP is sensitive to low frequencies in the range of 100 to $1500 \mathrm{~Hz}$ while the $\mathrm{BP}$ is sensitive to higher frequencies in the range between 1500 and $5000 \mathrm{~Hz}$ (Duellman et al., 1986). These ranges often vary from species to species and sometimes between sexes. The AP is generally larger than the BP. The AP hair cells possess both efferent and afferent synapses. The BP receives only afferent fibers (Flock and Elock, 1966; Simmons et al., 1992; Sobkowicz and Slapnick, 1994). Like birds, new hair cells are produced at a low level throughout life in amphibians (Kelley et al., 1992).

\section{Research on Frogs:}

Even though much has been studied about ototoxicity and regeneration in the auditory system of various animals, much of the focus has been on mammals, birds, and fish. Of the smaller amount of research carried out on amphibians, most studies have examined bullfrogs, Rana catesbeiana (Hernandez et al., 1995; Northcutt and Ronan, 1992; Seaman, 1991). Some of these studies have examined the effects of aminoglycosides on the morphology of 
auditory hair cells (Baird et al., 1993; Kroese et al., 1989). The present study is unique in being the first to examine, albeit indirectly, the physiological consequences of aminoglycoside treatment on the frog auditory system. This is also the first study to use high frequency and low frequency clicks to evoke specific amphibian or basilar papilla responses. 


\section{Methods and Materials}

The leopard frog Rana pipiens (Charles D. Sullivan Company, Nashville, TN) was utilized exclusively for this study. AlI animals were medium size adults (2 1/2 - 3 inches). All conditions and environments were standardized and kept constant. After shipment, the frogs were promptly placed in 20" $\times 10^{\prime \prime}$ tanks (usually five per tank). The temperature varied between 27-30 degrees Celsius. Approximately five crickets were fed weekly to each frog starting on their day of arrival. The mean mass \pm standard deviation of the frogs was 43.3

\pm 5.4 grams. Each test animal underwent surgery for electrode implantation between 3-10 days after arrival. After the surgeries and for the duration of testing, the frogs, in groups of three, were transferred to 8" $x$ 16" $^{\prime \prime}$ tanks.

The frogs were implanted under anesthesia (TMS, 3.0 mM, bicarbonate buffered) and placed dorsal side up on ice during the surgery to slow blood flow. The electrode implants consisted of three wires which performed the 
following functions: active-1, active-2 and reference. Each electrode consisted of a $2.5 \mathrm{~cm}$ length of tefloninsulated seven-strand stainless steel wire $1.15 \mathrm{~mm}$ in diameter, A-M systems). Approximately $10.0 \mathrm{~mm}$ of the insulation was removed from one end of the wire for amplifier connection. The implanted end of the electrode was stripped of $0.5 \mathrm{~mm}$ of its insulation. The active-1 electrode was placed within the cranium near the cochlear nucleus, the active-2 near the dorsal lymphatic sac, and the reference placed medially, between the eyes. The active electrodes were placed so as to detect the largest possible BAEP (Brainstem Auditory Evoked Potential). This placement was determined by trial and error. A 25 $\mu \mathrm{m}$ diameter drill bit was used to drill three holes through the cranium to provide access to the brain. Once positioned, the electrodes were sealed in place with cyanoacrylate adhesive (Nexaband Opthalmic) and dental cement. Once dried, the electrode cap and electrode bases were coated (Plasticdip) for added stability. For identification of the frogs a color code system was utilized. A combination of three colored beads was allowed to dry in the electrode cap created by the dental cement and Plasticdip. Animals were allowed 48 hours 
minimum recovery before testing. Commonly, the frogs exhibited normal behavior within 12 hours following the surgery. The implants usually lasted from three to six weeks. Each experiment was performed in a sound isolated room (IAC 1200 series).

The sound producing equipment consisted of a computer controlled "click" generator (Macintosh, GW instruments), equalizer (Rane FPE 13 Parametric), amplifier (Hafler P230) and loudspeaker (Radio Shack Minimus 7.0). Figure 1 shows the stimulus and recording equipment arrangement. The speaker was hung one meter directly above the test-frog. This arrangement enabled both tympani of the frog to be stimulated equally. The signal recording equipment consisted of signal amplifiers (Precision Instruments DAM 80, Tektronix 26A2) and a Digital Signal Analyzer (Tektronix DSA-601A). The amplifiers were bandpass limited ( $1 \mathrm{~Hz}-3000 \mathrm{~Hz}$ ). Using this arrangement, the brain signal was amplified approximately $10000 x$. The sound from the speaker at the position of the test animal was monitored using a measurement microphone and filter/amplifier(ACO Pacific and Krohn-Hite 3700 ). 
The averaging process was sophisticated in that a copy of the brain signal was routed to a custom-designed "artifact reject" circuit. This circuit validated the trigger pulse for averaging following each presentation of a stimulus click. Validation occurred only if the brain signal remained within a preset limit adjusted to be lower than muscle-generated artifacts present during any locomotor behavior. The circuit effectively looked back in time to examine the incoming signal from the brain. In this way, transient movement of the frog did not impair the on-going average and much time was saved during testing. If the brain signal contained too much artifact, from frog movement for example, the signal would not be averaged. Typically, between 250 and 500 averages were required, depending on the signal/noise ratio for the animal.

My method of determining thresholds for frogs utilized a visual detection method (Carey and Zelick, 1993) with a variation (step size) of the method of adjustment technique. This process involved starting with a loud click (20 dB attenuation, $94 \mathrm{~dB} \mathrm{SPL}$ ) and increasing the attenuation in large steps $(20,10,5 \mathrm{~dB}$ attn) (decreasing the $\mathrm{dB}$ SPI level) until no $A B R$ was 
seen. When no $A B R$ was present, the attenuation was decreased until the $A B R$ was once again present. Thus, a combination of over- and under-shooting was used in order to determine the threshold point.

Since the aminoglycosides may affect the amphibian and basilar papillae differently, specific clicks were generated so as to stimulate the AP, BP, or both. Thus, the frogs were exposed to three different test stimuli (Figure 2-5). The first of the clicks was a singleperiod $1 \mathrm{kHz}$ sinewave click. This click was generated from a waveform generator (TDT WGI) and for abbreviation is referred to as the "WGI" click. This click encompassed a wide band of frequencies sufficient to stimulate both the $A P$ and $B P$ while the two other clicks, a low frequency and high frequency click, were specifically designed to stimulate the amphibian and basilar papillae, respectively (Figure 6-8). A pulse generator (Krohn-Hite 2100) was used to trigger both the computer generated clicks as well as the waveform generated click at a rate of 11 per second which was found to be optimal in a previous study (Carey and Zelick, 1993). The computer generated clicks are referred to as the "AP" and "BP" clicks. 
The AP and BP clicks were actually composites of multiple sine waves (over the desired range). The sine waves were of coincidental phase at the middle of the click. Given the limitations of the computer and the mathematics involved, approximately $24 \mathrm{~Hz}$ steps were utilized between sinewaves. For example, if the first frequency was $200 \mathrm{~Hz}$, the second would be $224 \mathrm{~Hz}$, followed by $248 \mathrm{~Hz}$, and so on. The composite sinewaves produced a "train" of pulses as a consequence of falling in and out of phase with each other (constructive and destructive interference). A single pulse was sliced out of the "train" and further refined by applying a Hanning Window (cosine squared wave). This produced a click of the desired duration and spectral composition.

Initially, all of the frogs underwent sound testing to establish base-level "normal" ABRs for all three clicks and to determine the thresholds for each frog. Each frog was utilized as its own control in subsequent tests. Approximately six days of determining thresholds were needed per frog in order to establish each frog's normal thresholds. After normal thresholds were obtained, each test animal was injected with gentamicin sulfate (Sigma). Unlike several other studies on birds, 
fish, and amphibians in which gentamicin was injected systemically, a bilateral intraotic administration of gentamicin was utilized (Baird et al., 1992; Weisleder and Rubel, 1993; Lombarte et al., 1993). This method eliminated the possibility of systemic overdosage resulting in toxicity and other side effects. In addition, the intraotic administration permitted more certain control of dosage and destination of the gentamicin.

Using the intraotic approach required an estimation of the mean otic capsule volume in order to establish the final concentration of the gentamicin within the otic capsule (Table 1). This is the first time gentamicin was injected intraotically in this frog species. This also provides the approximate intraotic concentration of gentamicin. Several different frogs were utilized to provide a random sample. Four different methods were utilized to determine the otic capsule volume. The first method consisted of drilling two holes into each otic capsule. Dye was injected into one of the holes. When the dye was displaced from the second hole, the volume of dye injected was recorded. The second method involved drilling one hole into the otic capsule followed by 
suction removal of the fluid inside the capsule. The volume of fluid removed was recorded. Both of these methods utilized a Hamilton syringe for precise measurement. The third and fourth method involved the removal of the entire otic capsule. After the connective tissue was scraped away, the dimensions were recorded. The approximate volume was calculated assuming the capsule was (1) cuboidal, or (2) spherical. Averaging all four methods, the volume was estimated to be $16.8 \mu \mathrm{l}$ \pm 4.3 (SD). For the drug calculations, $15 \mu \mathrm{l}$ was utilized, to compensate for internal tissue and organs. The gentamicin solution was dissolved in low-calcium HEPES-buffered saline $(118 \mathrm{mM}$ sodium, $2 \mathrm{mM}$ potassium, 118 $\mathrm{mM}$ chloride, $4 \mathrm{mM} \mathrm{D}$ glucose and $10 \mathrm{mM}$ HEPES dissolved in distilled water). Control frogs were injected with the HEPES-buffered saline alone. Test frogs were injected with the HEPES solution with varing concentrations of gentamicin sulfate. Three different concentrations of gentamicin were utilized. The initial concentrations of $750 \mu \mathrm{M}, 1125 \mu \mathrm{M}$ and $1500 \mu \mathrm{M}$ were injected to yield approximate intraotic concentrations of $200 \mu \mathrm{M}, 300 \mu \mathrm{M}$ and $400 \mu \mathrm{M}$ respectively (see appendix for calculations). 
The gentamicin received from sigma contained components of C1, C2 and C1a with molecular weights of 477, 466 and 449 respectively. An average of 464 grams/mole was utilized (Kroese et al., 1989).

The injections were made bilaterally into the otic capsule under TMS anesthesia. To gain access to the otic capsules, frogs were placed ventral side up with the jaw held open using padded paperclips. This also kept the tongue away from the incision area. The connective tissue and muscle was scraped away in order to expose the otic capsule. A drill (45 $\mu \mathrm{m}$ diameter) was used to perforate the capsules. Two holes were drilled per capsule. This allowed the excess fluid to be displaced. A Hamilton syringe $(10 \mu I)$ was introduced into one of the holes and four microliters of the solution was carefully injected. The holes were covered with dental cement and the frogs were allowed to recover overnight. Testing for thresholds was continued the following day until the thresholds returned to the frogs' normal values. 


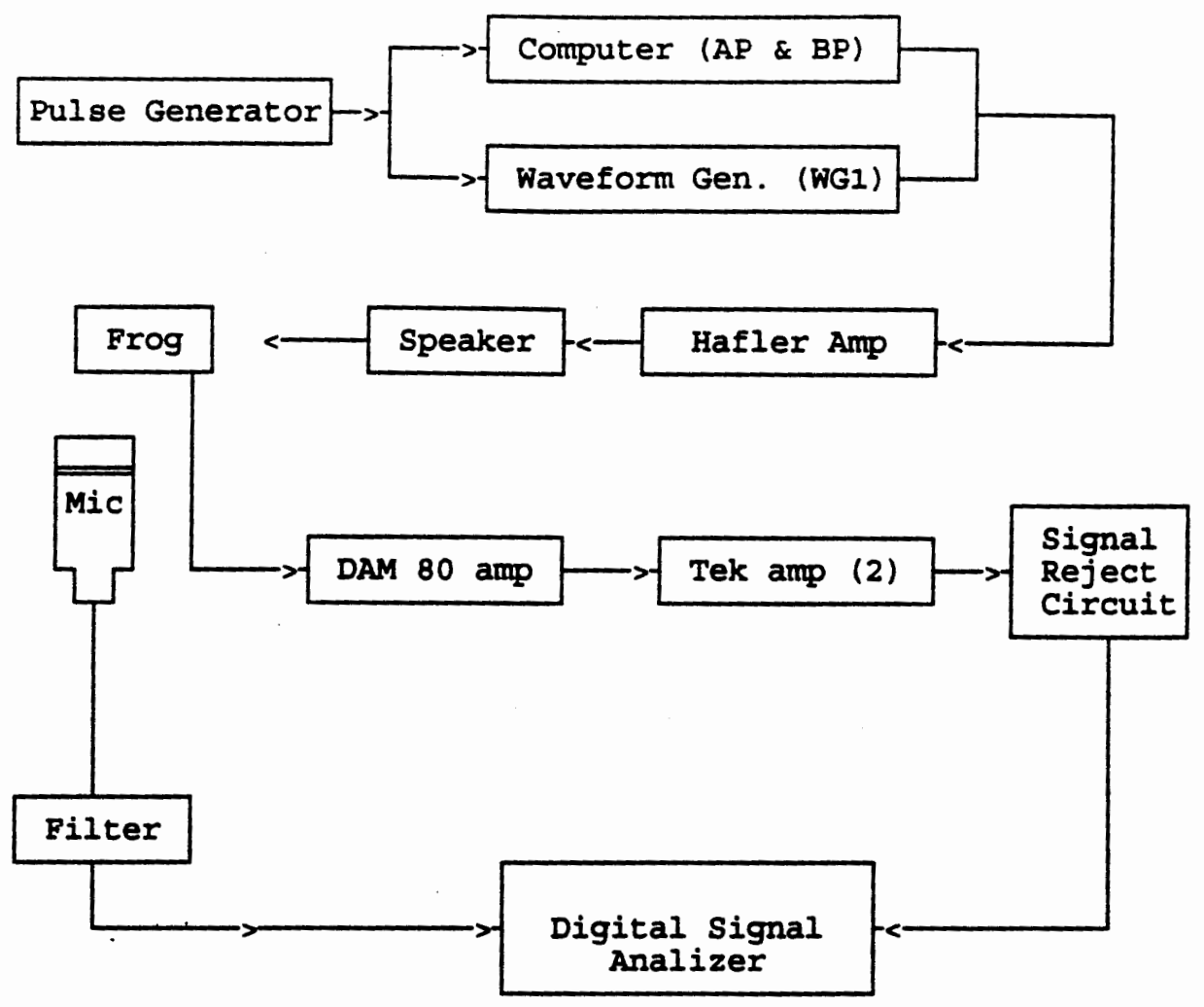

Figure 1. Stimulus and recording arrangement for obtaining ABRs. The clicks, generated by the computer and waveform generator, are triggered by the pulse generator. The clicks are amplified to drive the speaker. The brain signals are amplified and any artifact present is rejected by the signal reject circuit. The signal is averaged and viewed with the digital signal analyzer. The microphone is used to monitor the clicks. 

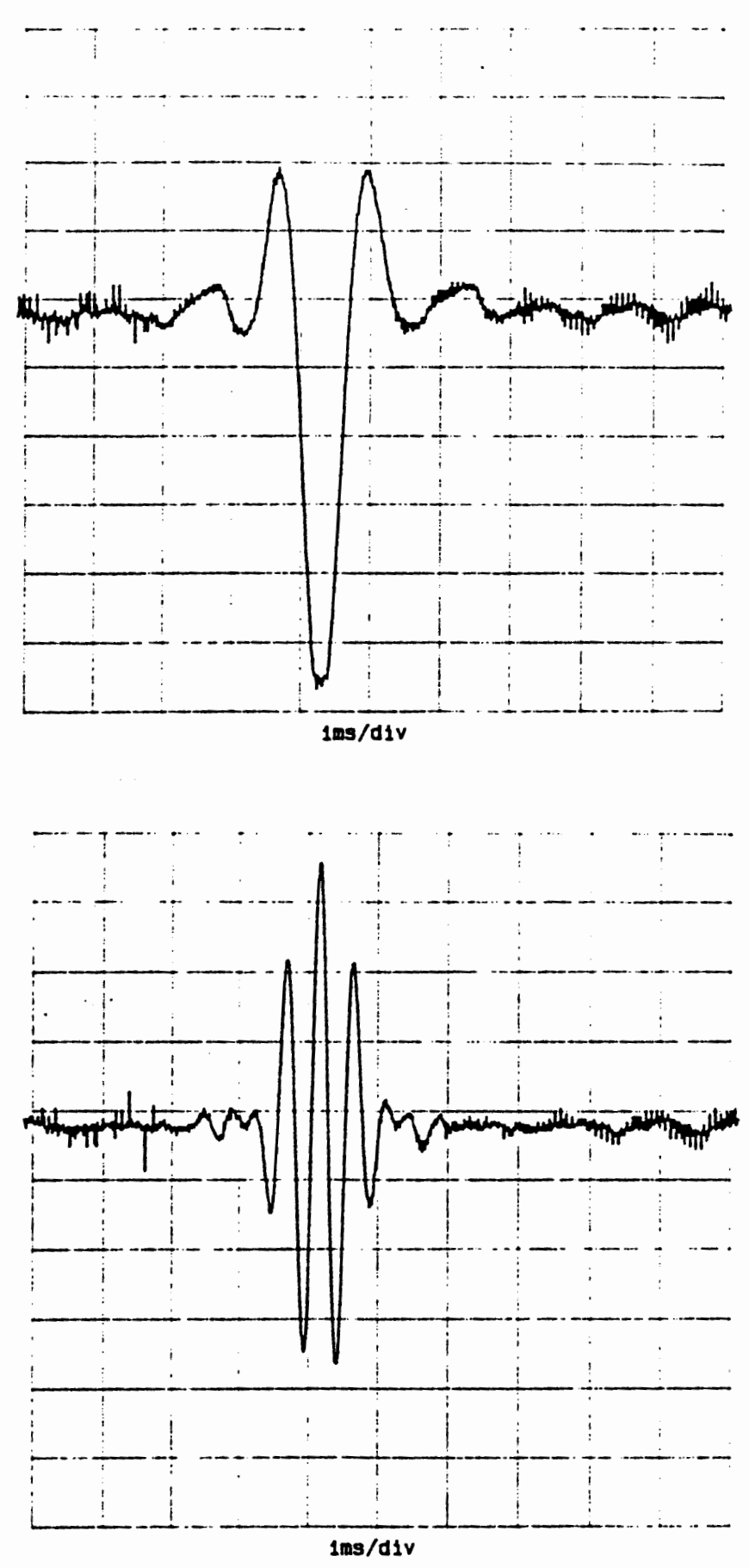

Figure 2. Electrical representations of the AP click (top) and BP click (bottom). Note durations are less then $3 \mathrm{~ms}$. The $\mathrm{Y}$-axis is arbitrary voltage units. 


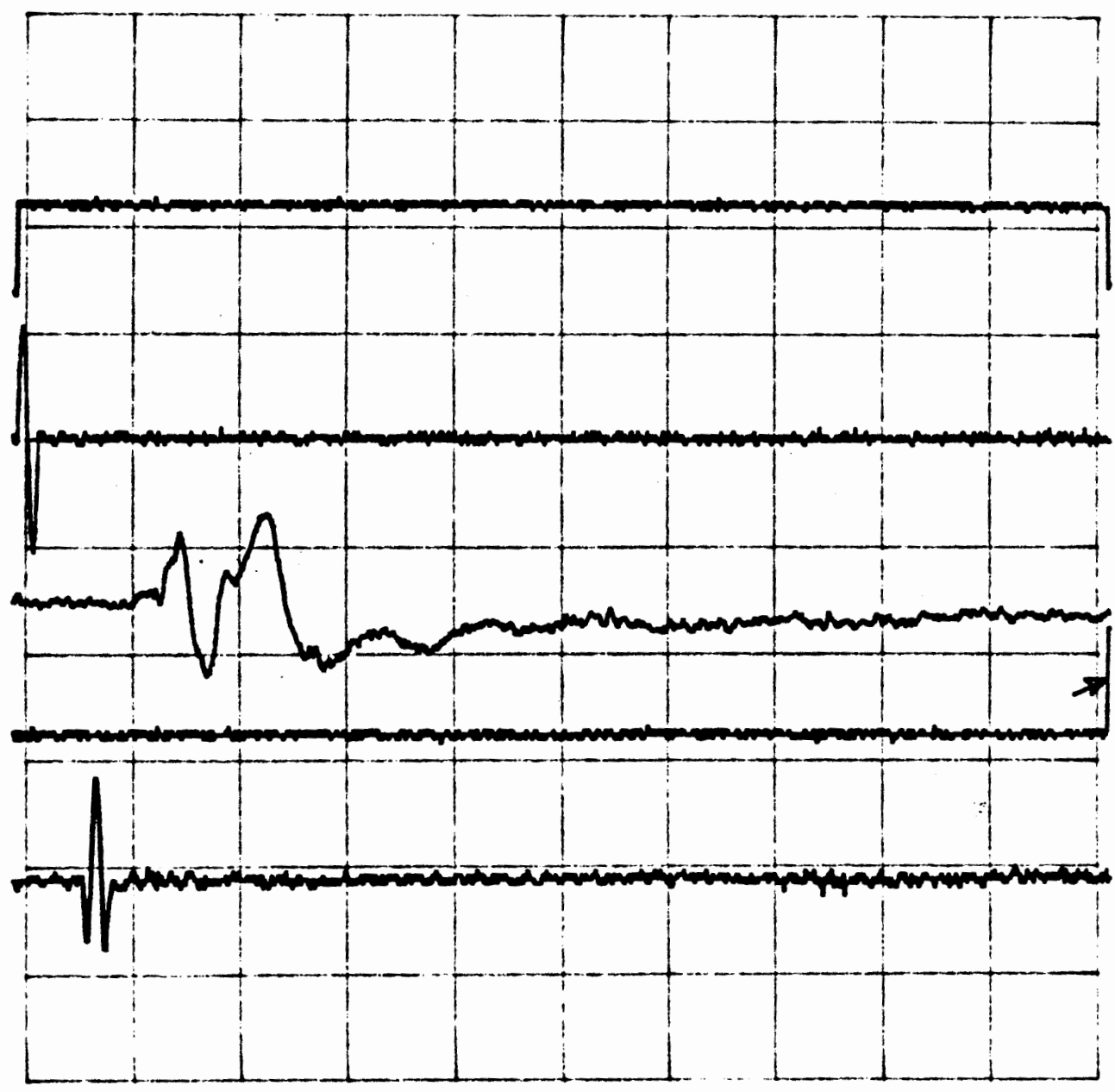

$5 \mathrm{~ms} / \mathrm{d}$ Iv

Figure 3. Time relationship of test signals. The top trace shows the triggers for the click generator which produces a sinewave (second trace). The third trace is the resulting ABR. The fourth trace is the validation signal (arrow; see methods). This is also triggered by the main trigger (top trace). The bottom trace is the acoustic signal picked up by the microphone. Notice the delay between the original click, the microphone, and the ABR signal produced. The Y-axis is arbitrary units. 


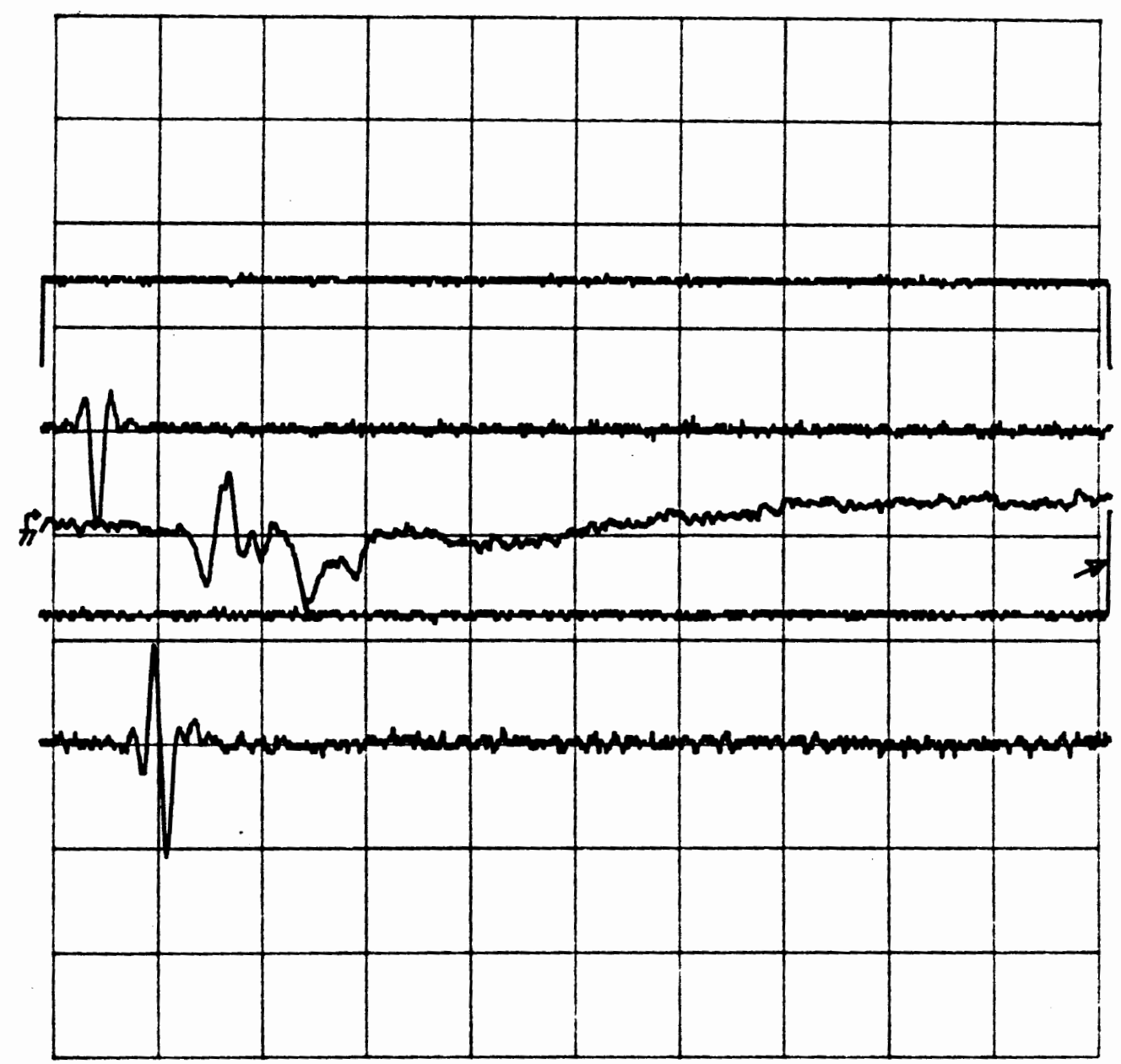

5ns/div

Figure 4. Similar to the previous figure (Figure 4), the trigger (top trace) causes the computer to generate a click, here, the AP electrical signal (second trace). The ABR waveform morphology (third trace) is different then that of the WGI ABR morphology. The fourth trace represents the validation signal. The last trace is the microphone signal. 


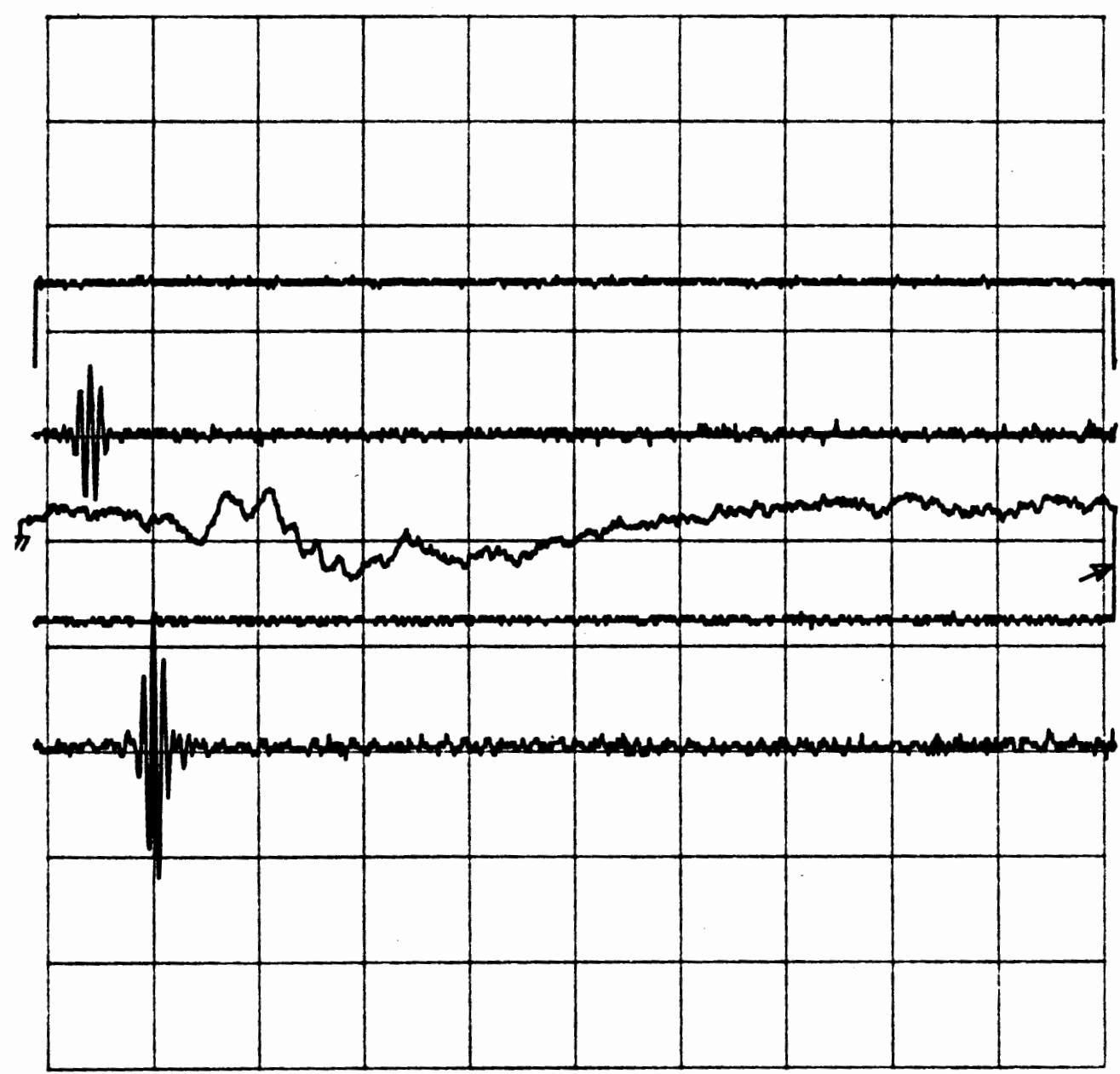

$5 \mathrm{~ms} / \mathrm{div}$

Figure 5. BP click. Traces same as Figure 4. The ABR (third trace) has a different waveform morphology than the WGI or AP clicks. 


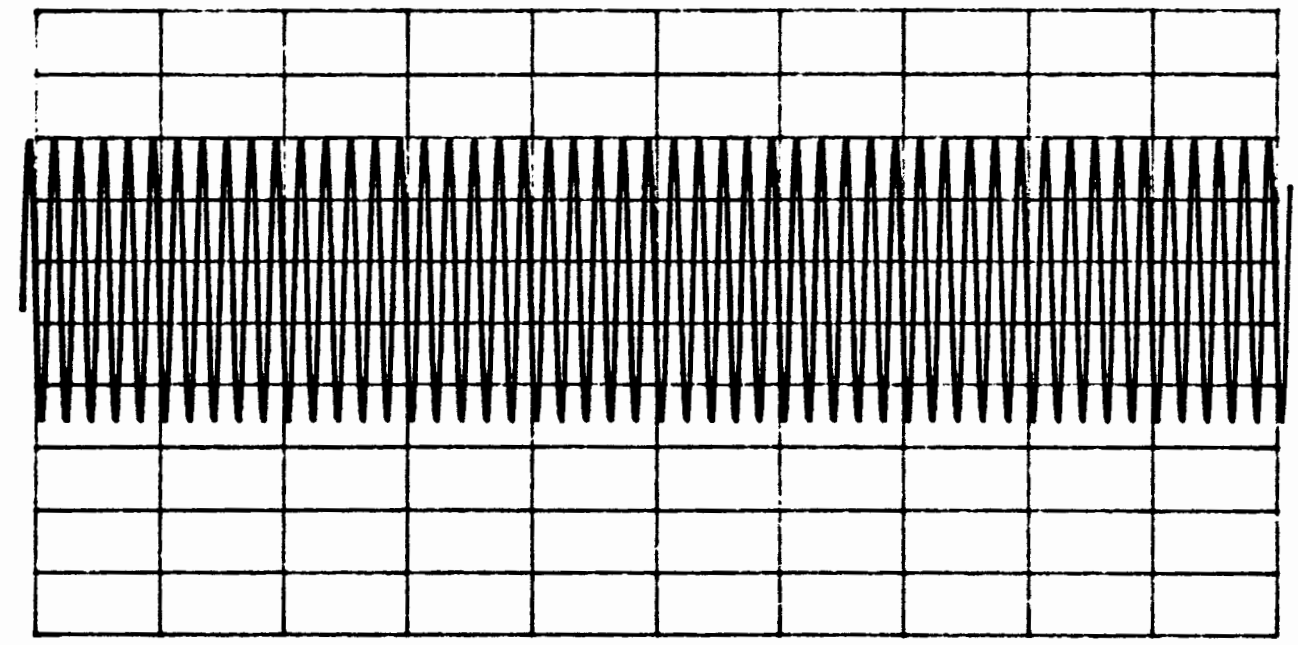

$5 m s / d i v$

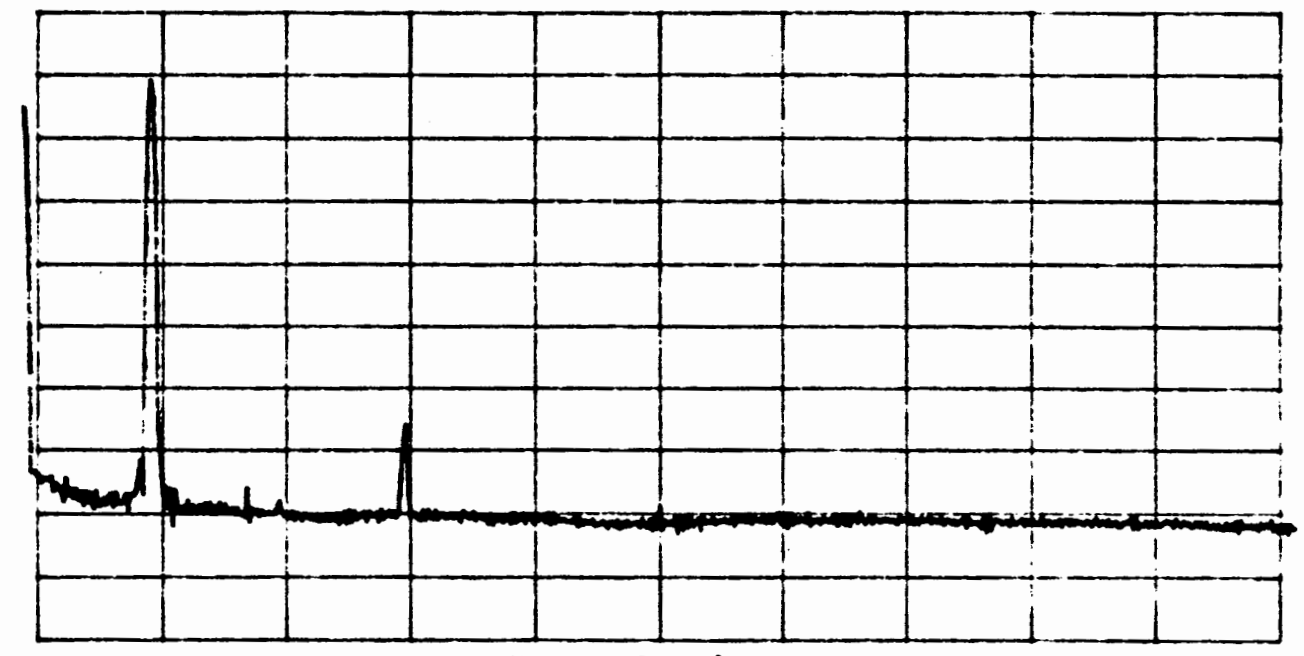

$976.562 \mathrm{~Hz} / \mathrm{d}$ iv

Figure 6. Spectral purity of sound delivery system. Top: A continuous sinewave tone $(1000 \mathrm{~Hz})$. Below: The corresponding frequency spectrum. The small peak at $3000 \mathrm{~Hz}$ is the 2 nd harmonic. The frequency spectrum was averaged 512 times. All Y-axis units are arbitrary units. 


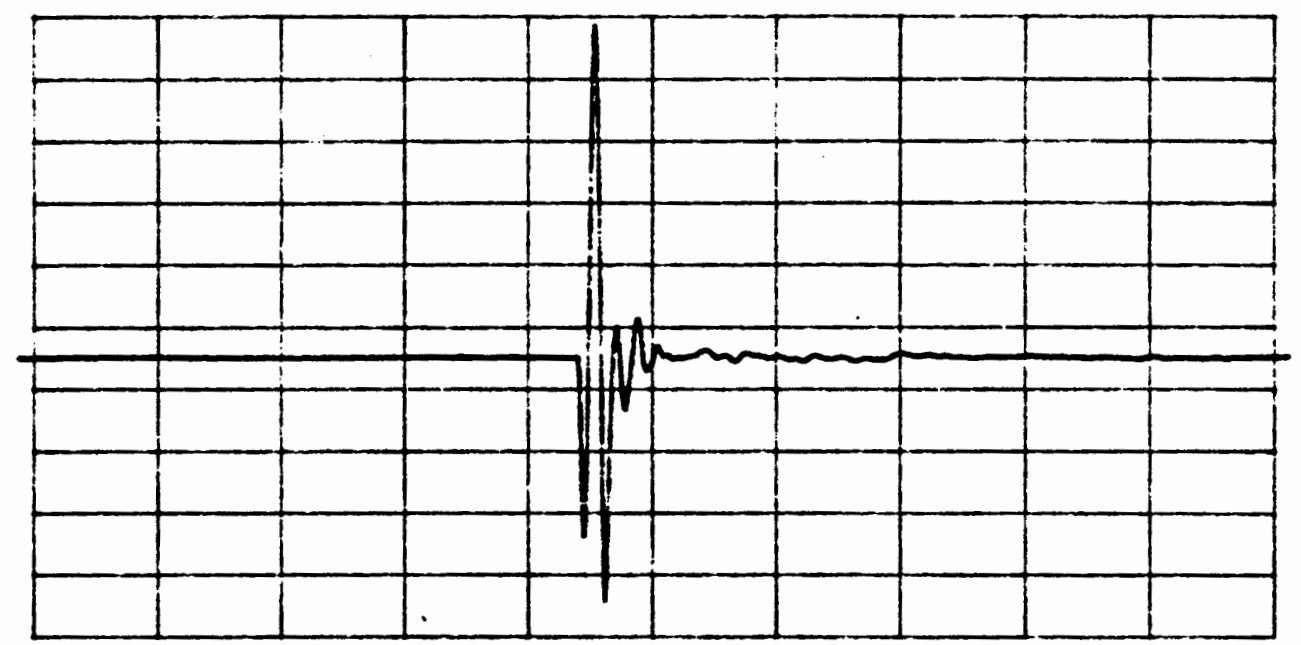

$5 \mathrm{~ms} / \mathrm{div}$

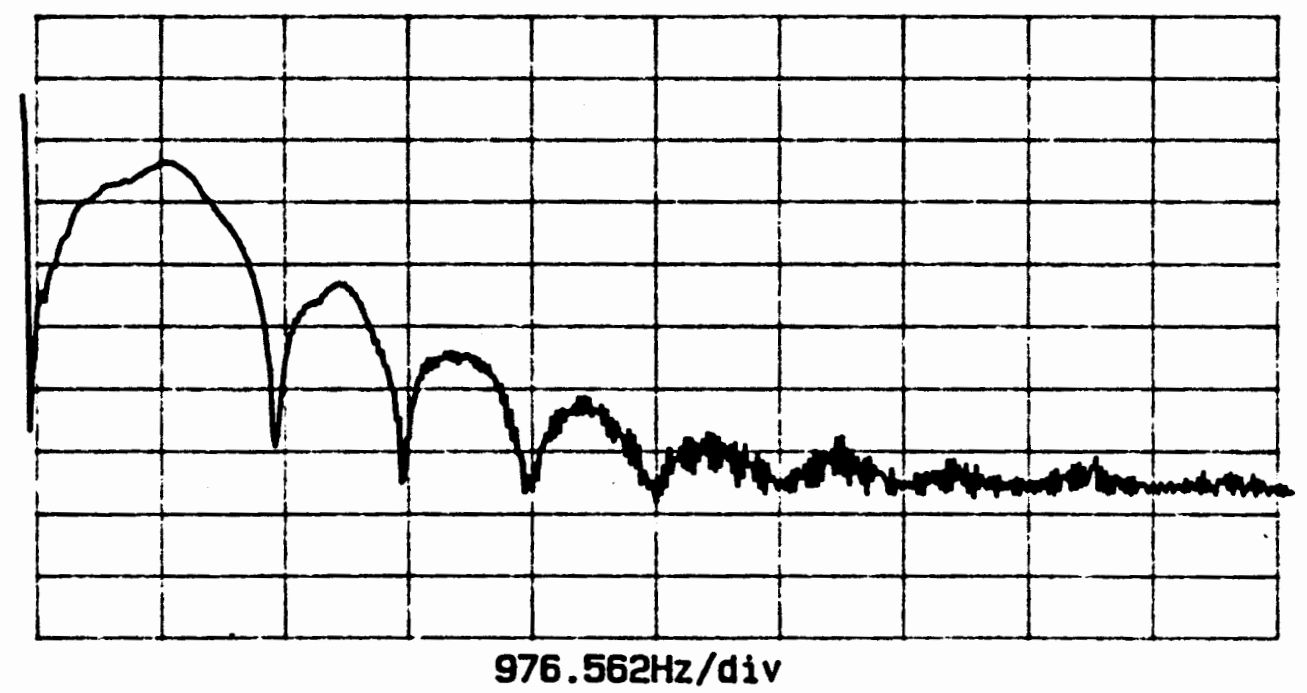

Figure 7. Top: A single period sinewave click (TDT click). Bottom: The corresponding frequency spectrum. This spectrum (averaged 512 times) is normal and characteristic of such a click. All Y-axis units are arbitrary voltage units. 


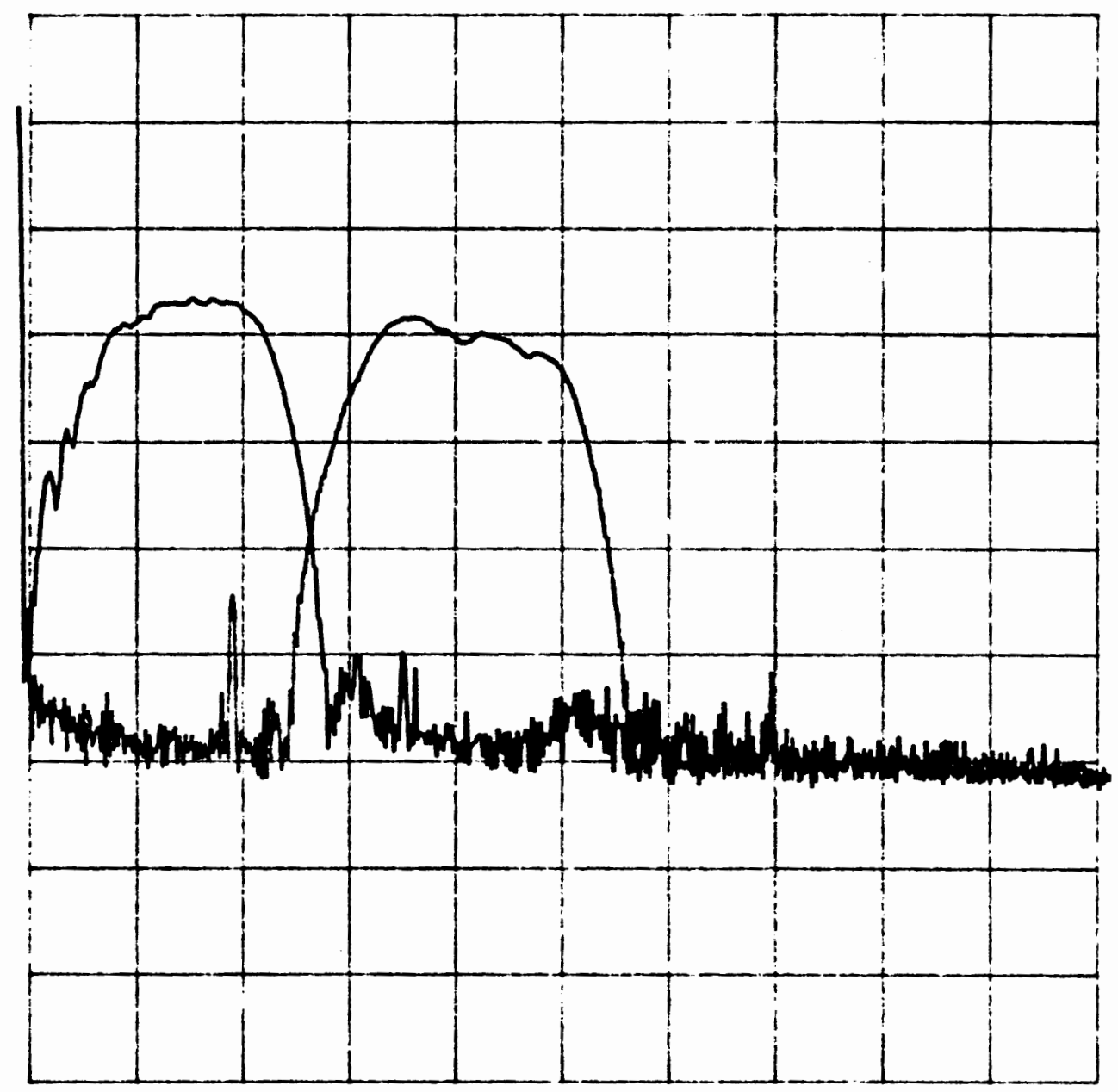

$488.281 \mathrm{~Hz} / \mathrm{d} I \mathrm{~V}$

Figure 8. Frequency spectra of the AP and BP acoustic signals. The AP click has most of it's energy between 200-1100 Hz while the BP click mainly contains frequencies between $1100-2200 \mathrm{~Hz}$. A small overlap is also visible between 1000 and $1100 \mathrm{~Hz}$. Left edge of X-axis is approximately $0 \mathrm{~Hz}$. Y-axis is $10 \mathrm{~dB} /$ division. 
Method I - Iniected Ink

\begin{tabular}{lr}
\hline Frog \# & amt. injected \\
\hline Frog 1 & 16 \\
& 15 \\
Frog 2 & 18 \\
& 19 \\
Frog 3 & 14 \\
& 13 \\
Frog 4 & 13 \\
Frog 5 & 25 \\
& \\
\hline Mean: & 16.6 \\
\hline St. Dov: & 4.0 \\
\hline
\end{tabular}

Method III - Calc, of Sphere

\begin{tabular}{lr}
\hline Frog \# & Otic Capsule Volume \\
\hline Frog 1 & 12.1 \\
Frog 2 & 7.8 \\
& 14.7 \\
Frog 3 & 14.6 \\
& 11.1 \\
& 0.7 \\
\hline Mean: & \\
\hline St. Dev: & 11.7 \\
\hline
\end{tabular}

Mean of Method I-N:

Standard deviation of Mothod I-W:
Method II-Suction Removal

\begin{tabular}{lr}
\hline Frog \# & amt. removed \\
\hline Frog 1 & 18 \\
Frog 2 & 17 \\
& 13 \\
Frog 3 & 15 \\
& 20 \\
\hline Mean: & \\
\hline St. Dev: & 16.6 \\
\hline
\end{tabular}

Method N-Calc. of Cube

\begin{tabular}{lr}
\hline Frog \# & Otic Capsule Volume \\
\hline Frog 1 & 23.1 \\
Frog 2 & 14.8 \\
& 28.1 \\
Frog 3 & 27.8 \\
& 21.2 \\
& 18.6 \\
\hline Mean: & 22.3 \\
\hline St. Dev: & 5.2 \\
\hline
\end{tabular}

16.8

4.3

Table I. The four methods for the estimation of the otic capsule volume. 


\section{Results}

\section{ABRs :}

ABRs from a typical single frog recorded from pretreatment through 14 days post-treatment are shown in Figures 9-12. The addition of gentamicin has an obvious effect on the ABR morphology. Absolute peak latencies shift accordingly with the changes in sound pressure level (SPL). With a decreased SPL (increased attenuation), the latencies increased and the amplitude of the ABRs decreased. The corresponding threshold shifts are plotted (Figure 13 top). The ABRs showing the waveform morphology changes correspond to two days before treatment and three, 10 and 13 days post-treatment. This test included only the WGI click. A typical frog showing threshold shifts for injections of $300 \mu \mathrm{M}$ gentamicin concentrations is also shown (Figure 13 bottom). These data include threshold shifts for the $A P$ and $B P$ clicks in addition to the WGI click. 


\section{Threshold and Recovery:}

Figure 14 shows the control and mean of frogs receiving $200 \mu \mathrm{M}$ gentamicin concentrations. The time scale does not completely correspond to that in the other trials since the control frogs were injected with the HEPES-buffered control solution five days prior to the test frogs. As expected, the control group showed little change in threshold. The mean threshold shift for frogs receiving $200 \mu \mathrm{M}$ gentamicin injections was approximately five $d B$. Only three frogs were used for the $200 \mu \mathrm{M}$ injections. Because the shift was small and had no effect on one of the frogs, it was decided to increase the concentration to $300 \mu \mathrm{M}$. Baird et al. (1993) found that this concentration of gentamicin had little or no effect on the morphology of frog vestibular hair cells.

Two different groups of frogs received $300 \mu \mathrm{M}$ gentamicin injections (Figure 15-16). However, only one control group was utilized which showed no significant threshold change. A total of 12 frogs was utilized for the $300 \mu \mathrm{M}$ trials. The mean threshold shift for frogs receiving $300 \mu \mathrm{M}$ gentamicin injections was between 5-10 $\mathrm{dB}$. 
In frogs receiving $400 \mu \mathrm{M}$ drug treatments, threshold shifts of 10-20 $\mathrm{dB}$ were observed (Figure 17-18). More than 20 frogs were utilized for the $400 \mu \mathrm{M}$ trials. The first trial of $400 \mu \mathrm{M}$ injections produced pronounced threshold shifts for which total recovery was not observed. This is attributed to high frog mortality. Unlike their responses to other drug concentrations, erratic frog behavior was noted for the first time with the $400 \mu \mathrm{M}$ concentration of gentamicin (first trial only). A total of eight frogs was utilized for trial one, six test animals and two controls. Two frogs, including a control frog died on the third day. On the fifth day, another test frog died. Before they died, all of the frogs appeared "sickly." They also exhibited balance problems and were leaning to one side. Often, one leg would be outstretched. They did not jump and remained still. This included not trying to jump out of tanks even when the lids were removed, a behavior uncharacteristic for frogs. Before the thresholds could completely recover, most of the frogs died. No adverse vestibular effects were observed with the second trial of $400 \mu \mathrm{M}$ frogs. 
In all trials, threshold shifts were seen as early as one day post-injection. Also, recovery began between day three and five post-injection. In both $300 \mu \mathrm{M}$ trials and the first trial of $400 \mu \mathrm{M}$, threshold increases were seen approximately six days post-injection.

Not only did the threshold shifts depend on the dosage concentration of gentamicin; they were also potency dependent. For example, trial two of the $300 \mu \mathrm{M}$ (Figure 16) injections utilized yielded a smaller change in threshold than the first trial. The gentamicin solution made for this trial was the same used for the first $300 \mu \mathrm{M}$ (Figure 15) trial and was two weeks old. The potency effect is also obvious from mean threshold differences between the two $400 \mu \mathrm{M}$ (Figure 17-18) concentration trials. The gentamicin solution used for the second $400 \mu \mathrm{M}$ trial was six days old. However, the second $400 \mu \mathrm{M}$ trial shows significant threshold shifts. It should be noted that on graphs showing threshold shifts (Figure 14-18), three pre-treatment thresholds (day $-3,-2$ and -1 ) were averaged. Thresholds recorded three days pre-treatment were usually stable and represented a "normal" threshold. Each threshold 
measurement was normalized by subtracting the measurement from the pre-treatment average. The means for each frog were plotted and standard deviations were calculated for all trials except for the controls and the $200 \mu \mathrm{M}$ trial (Figure 14 bottom). 


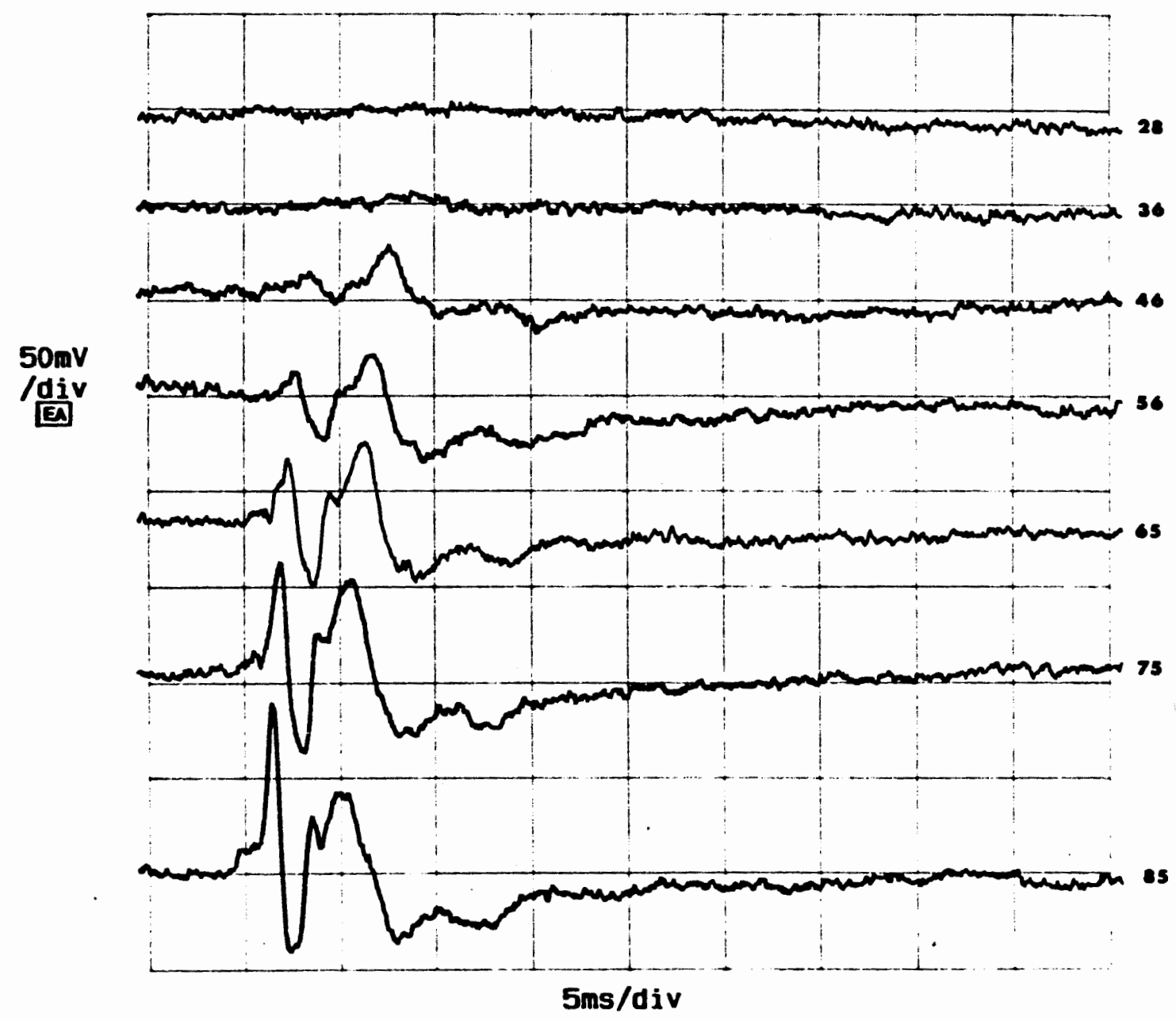

Figure 9. ABR responses recorded two days pre-treatment with gentamicin. Numbers on the right correspond to decibels (dB) SPL. 


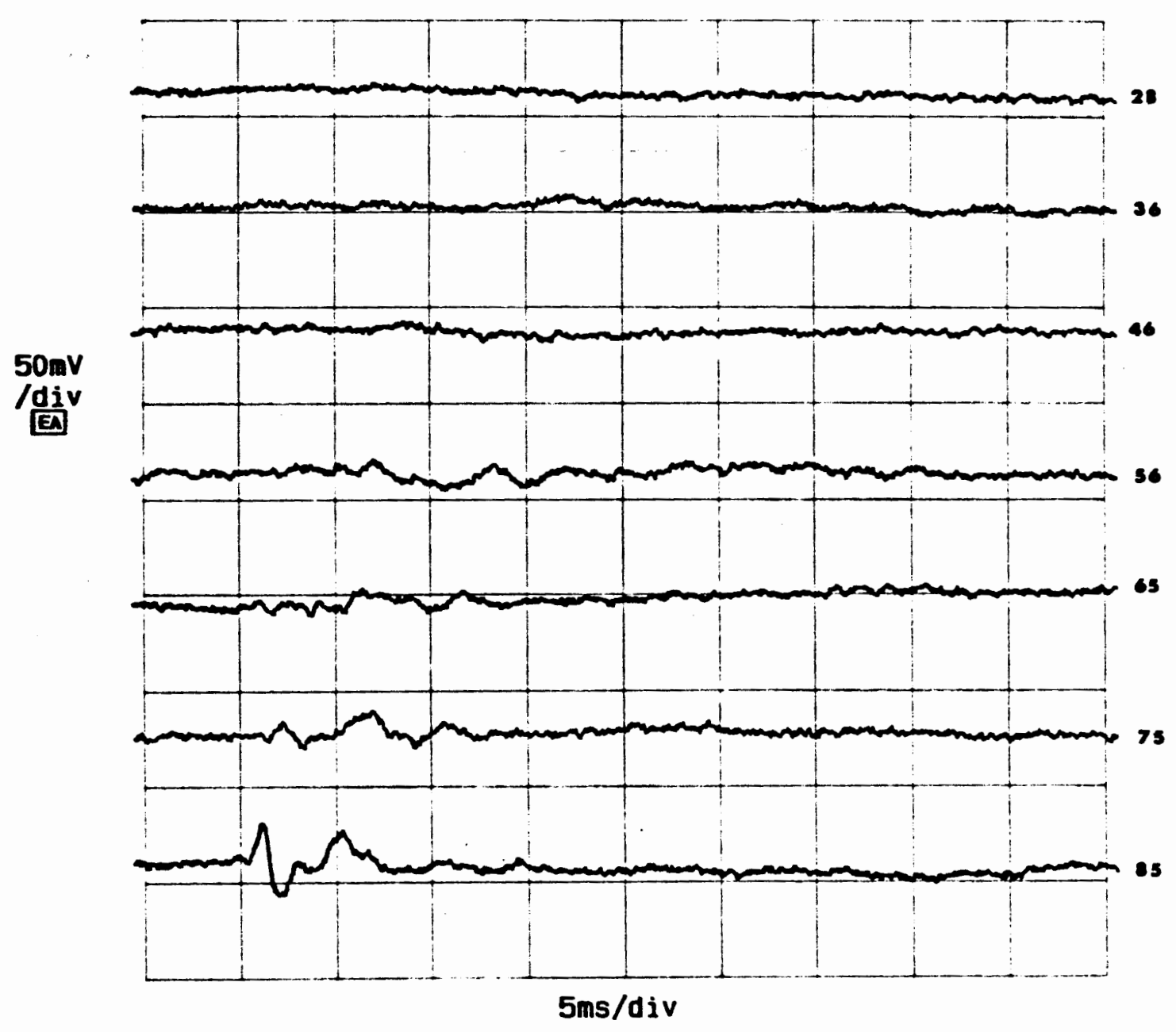

Figure 10. 3-day Recovery of threshold. ABRs from same test animal as Figure 9. Threshold shift is pronounced. 


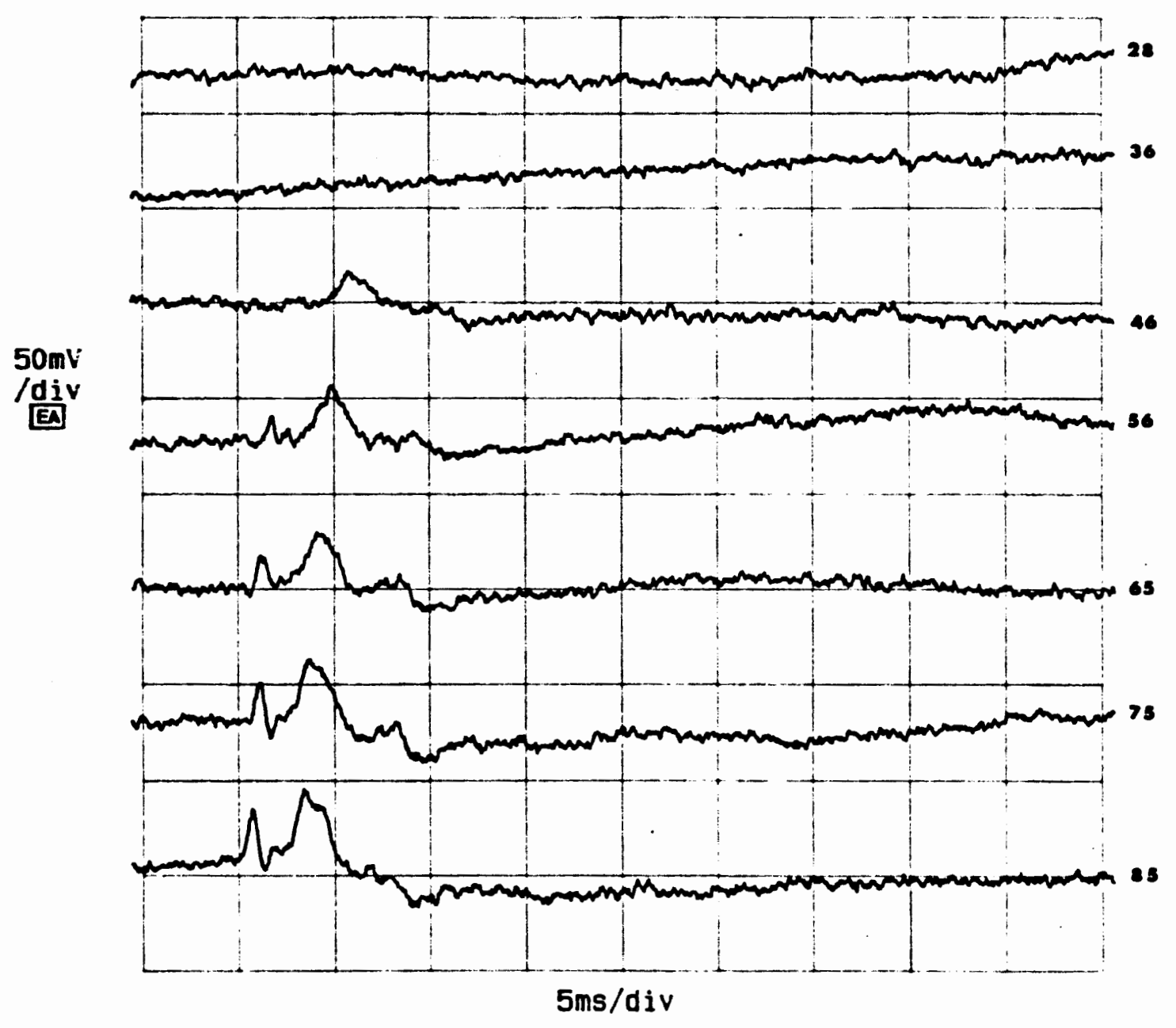

Figure 11. 10-day Recovery of threshold. ABRs from same test animal as Figure 910. Note, the waveform morphology is still different. 


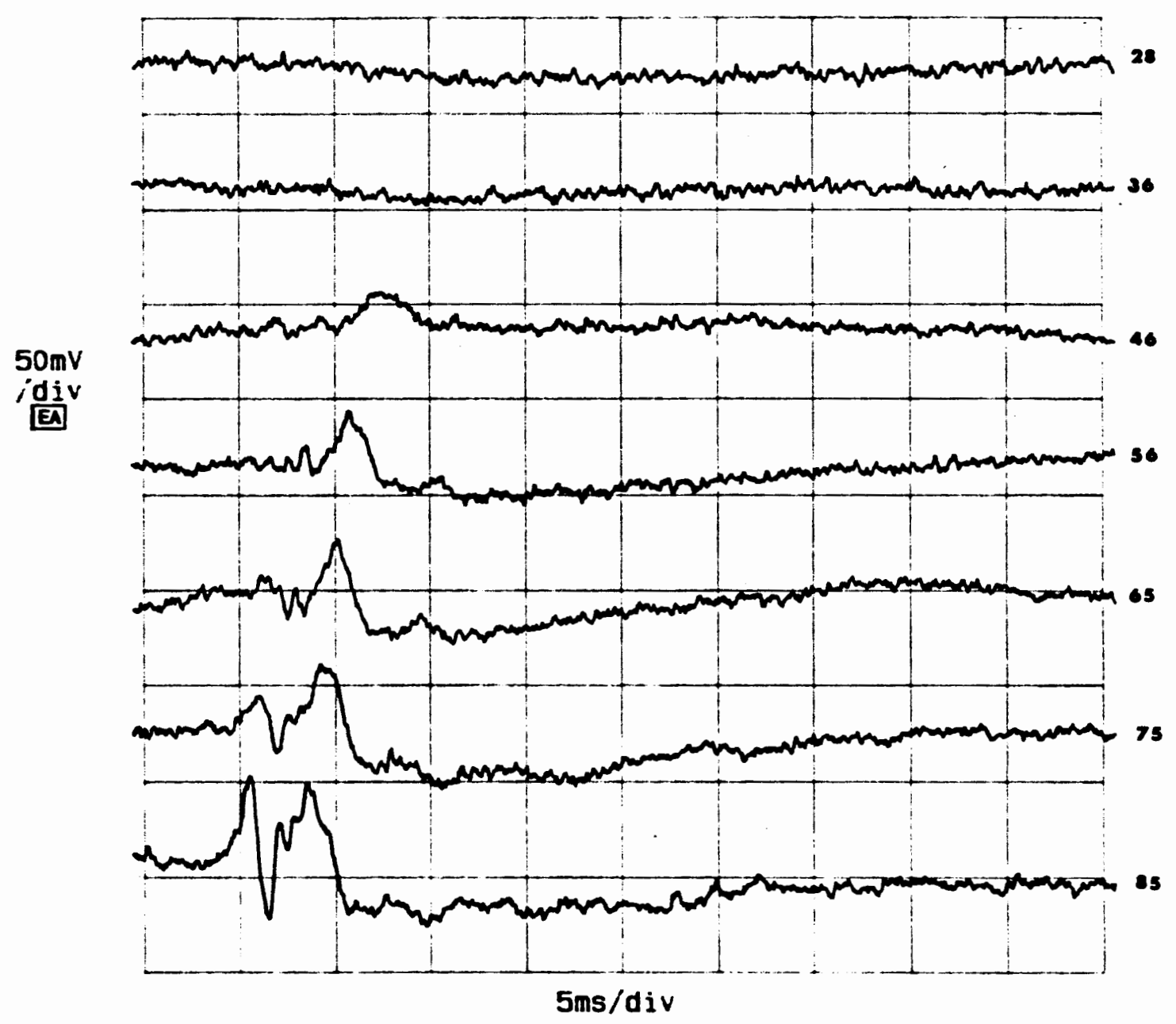

Figure 12. 13-day Recovery of threshold. Both threshold and waveform morphology are similar to the pre-treatment situation. 

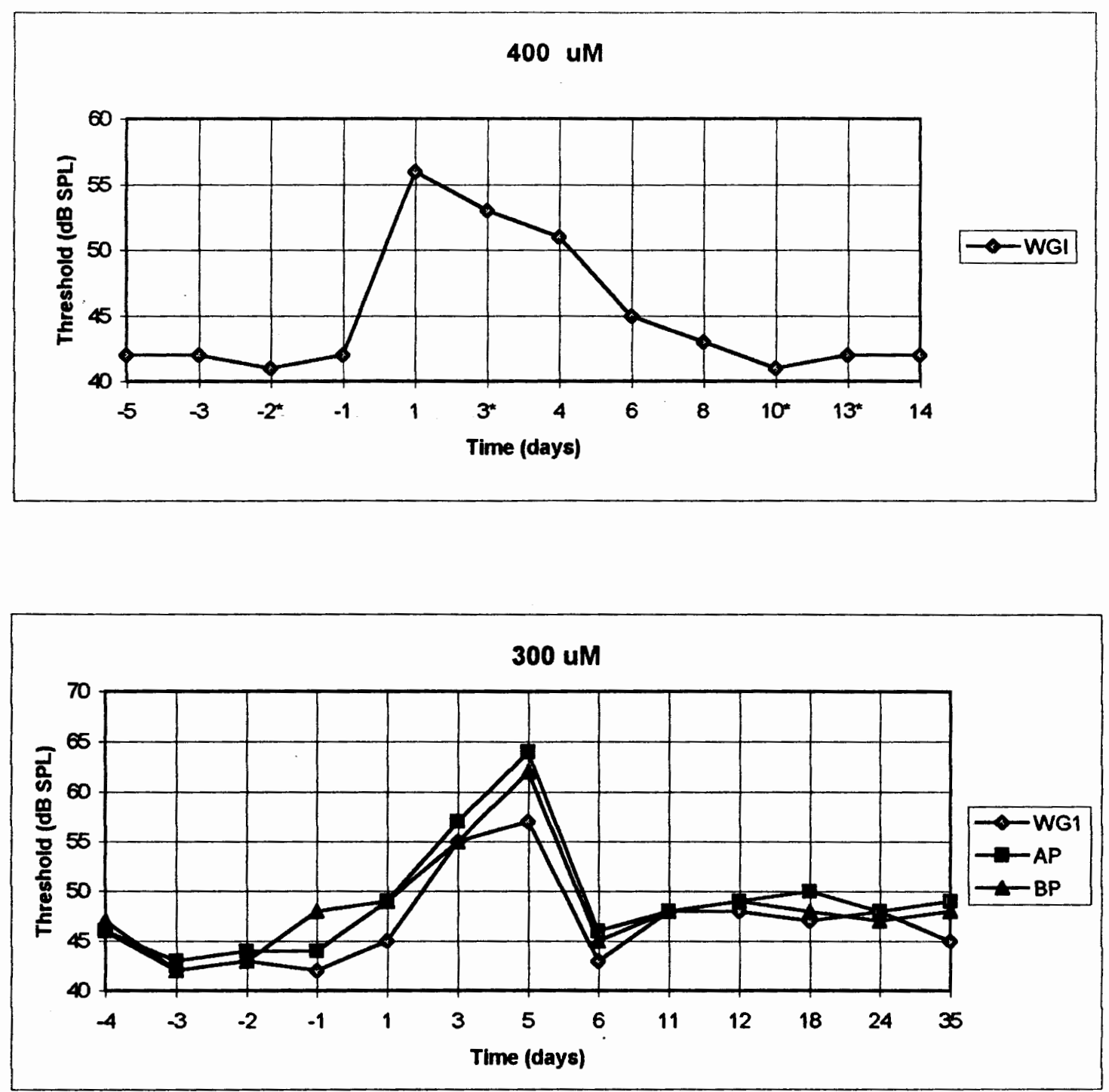

Figure 13. Top: Threshold change and recovery over 20 days. Days marked with an asterisk correspond to ABR data from same test animal as Figure 9-12. Bottom: Typical threshold from one frog receiving $300 \mu \mathrm{M}$ gentamicin concentration showing similarity of threshold change for AP and BP. 

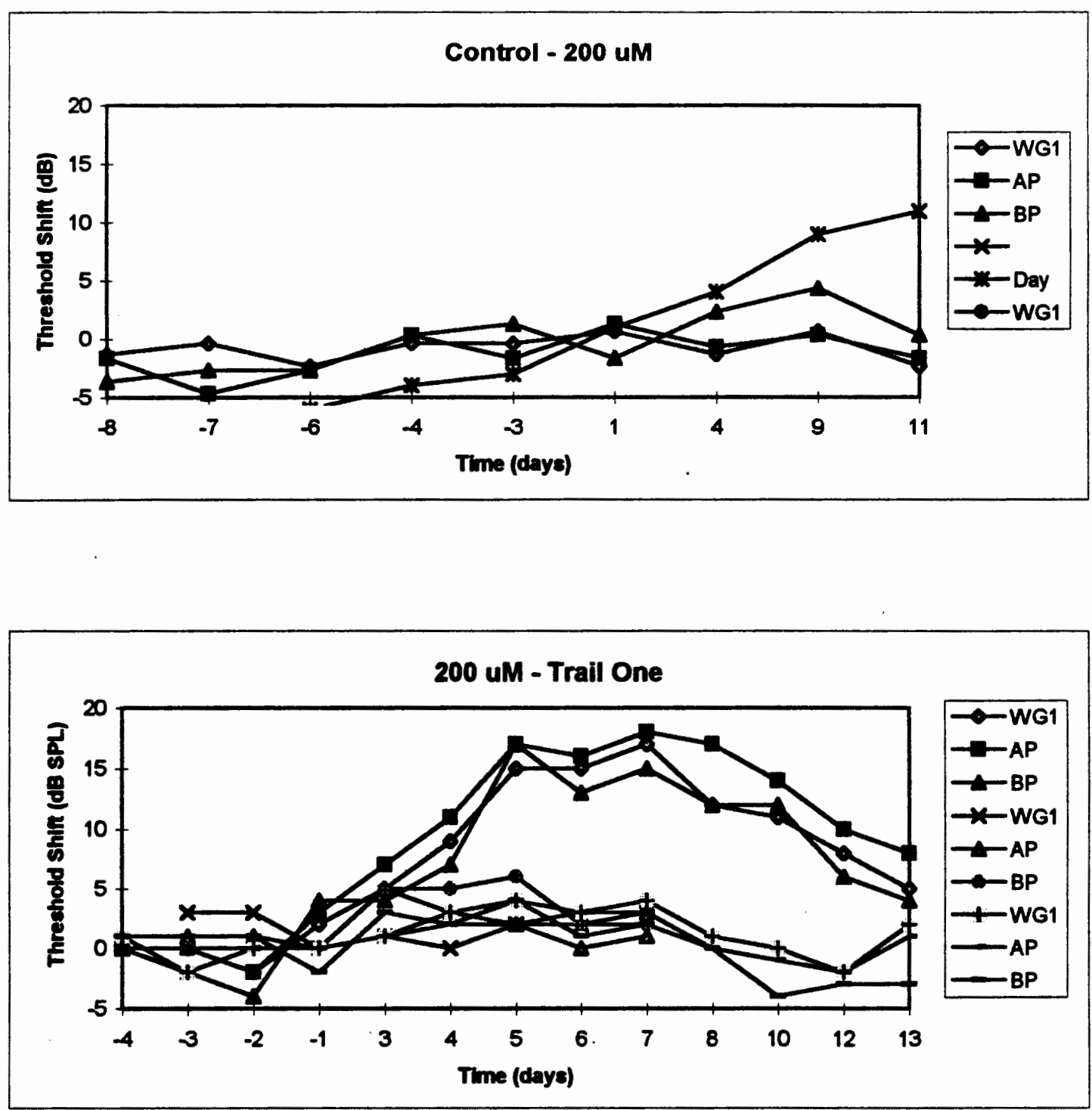

Figure 14. Top: Control group for $200 \mu \mathrm{M}$ frogs. Bottom: Threshold shift for three frogs given $200 \mu \mathrm{M}$ gentamicin. Control frogs started six days earlier than test frogs. 

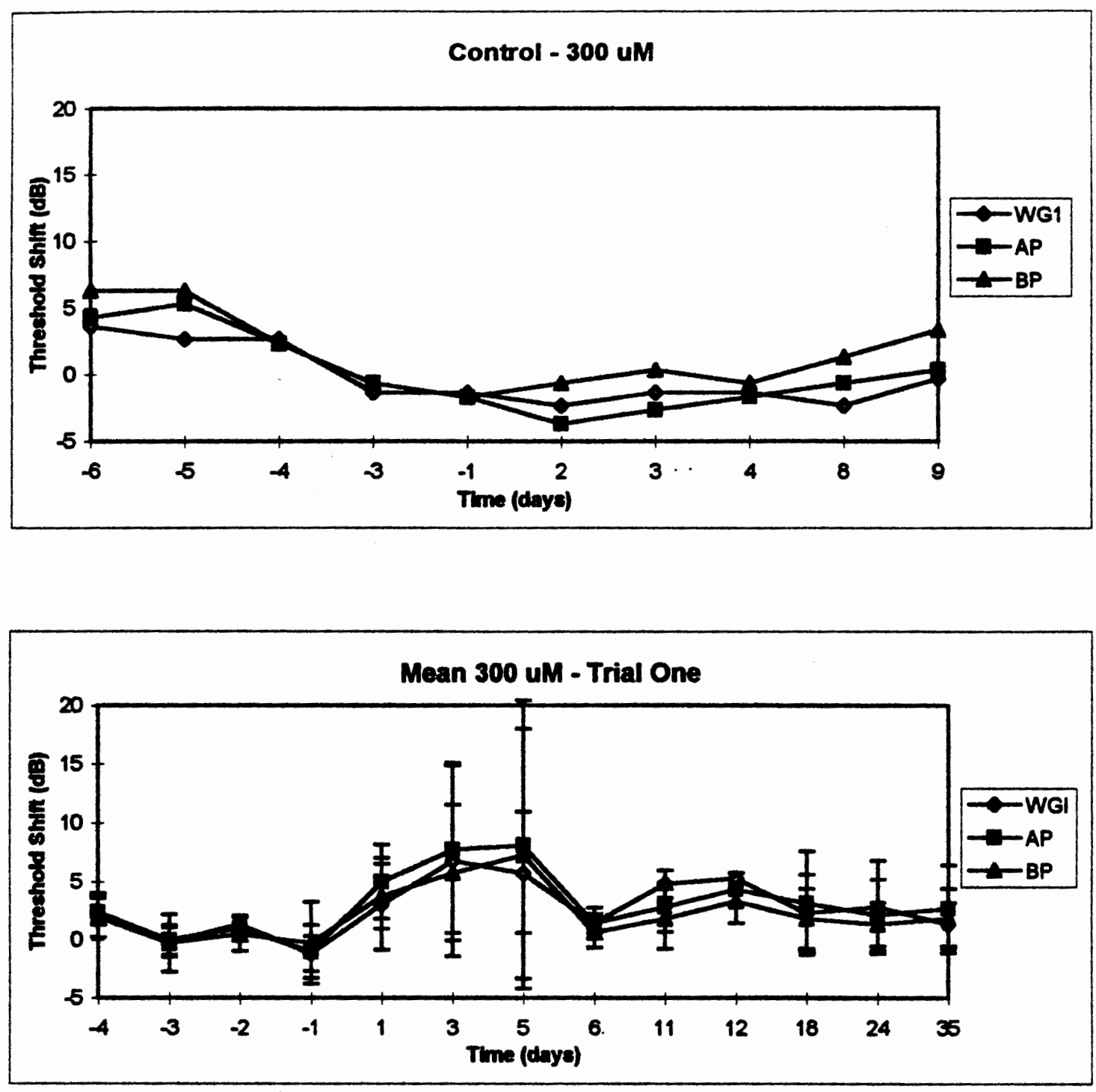

Figure 15. Top: Control group for $300 \mu \mathrm{M}$ frogs. Bottom: Trial One threshold shift of frogs given $300 \mu \mathrm{M}$ gentamicin. (Mean $\pm \mathrm{SD}$ for WGI, AP, and BP clicks, $\mathrm{n}=5$ ). Since only one control group was used for the $300 \mu \mathrm{M}$ injections, the control groups are the same for Figure 15 and 16. 

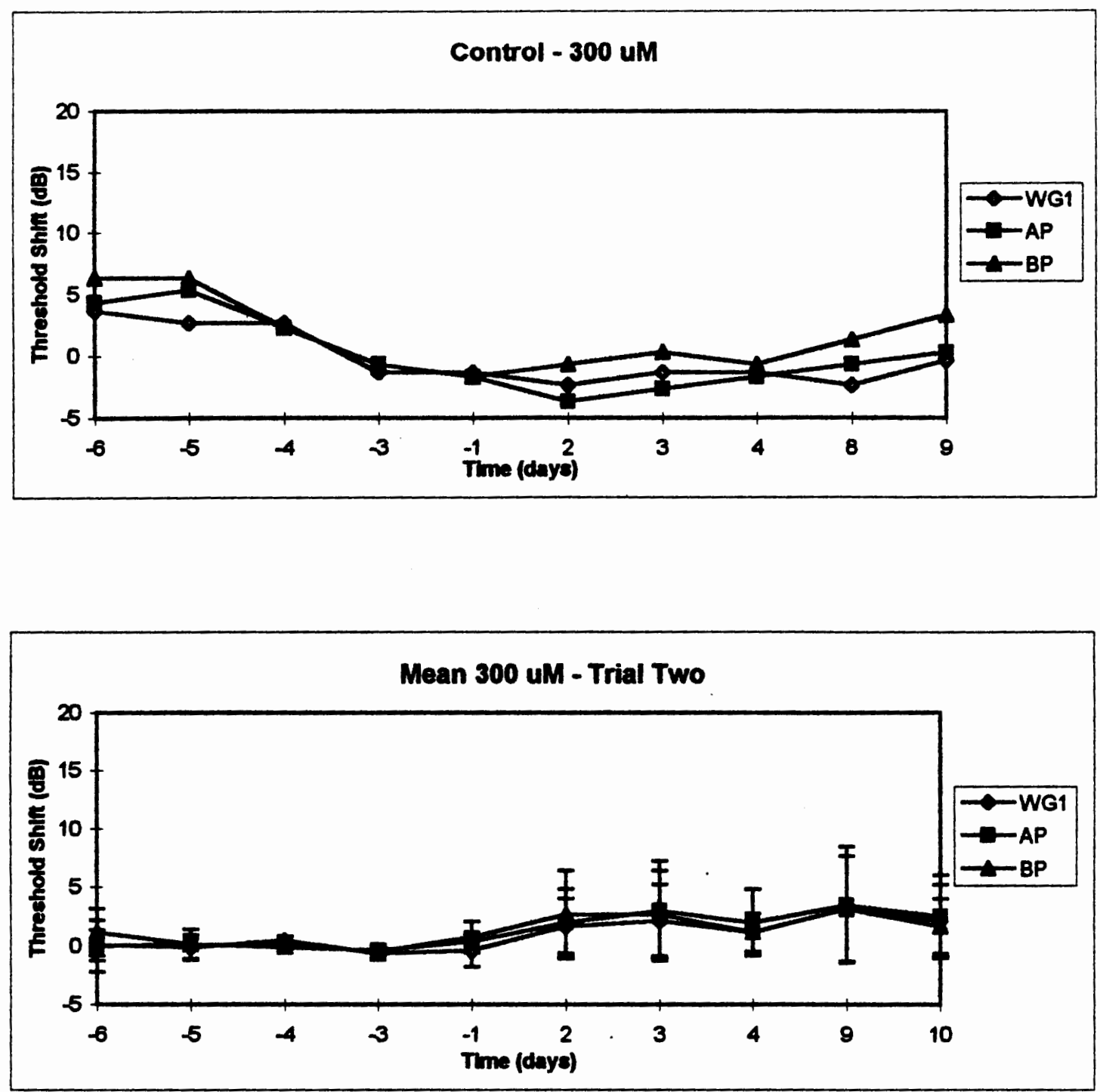

Figure 16. Top: Control group for $300 \mu \mathrm{M}$ frogs. Bottom: Trial Two threshold shift of frogs given $300 \mu \mathrm{M}$ gentamicin. (Mean \pm SD for WGI, AP, and BP clicks, $\mathrm{n}=6$ ). 

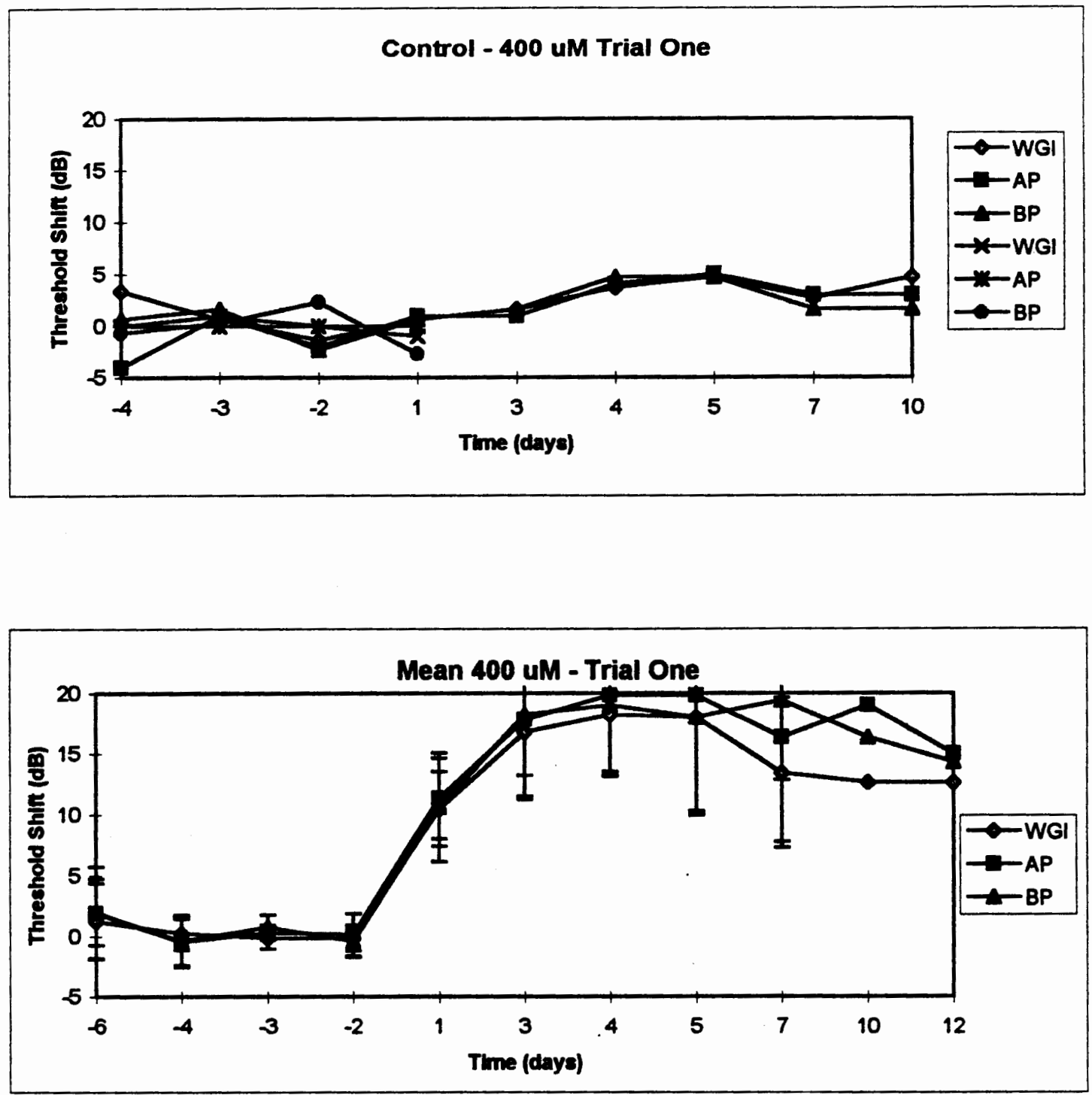

Figure 17. Top: Control group for $400 \mu \mathrm{M}$ frogs. Bottom: Trial One threshold shift of frogs given $400 \mu \mathrm{M}$ gentamicin. Threshold shifts were between 15-20 dB. However, high mortality rates and suspected infection prevented return to "normal" thresholds. (Mean \pm SD for WGI, AP, and BP clicks, $n=8$ ). 

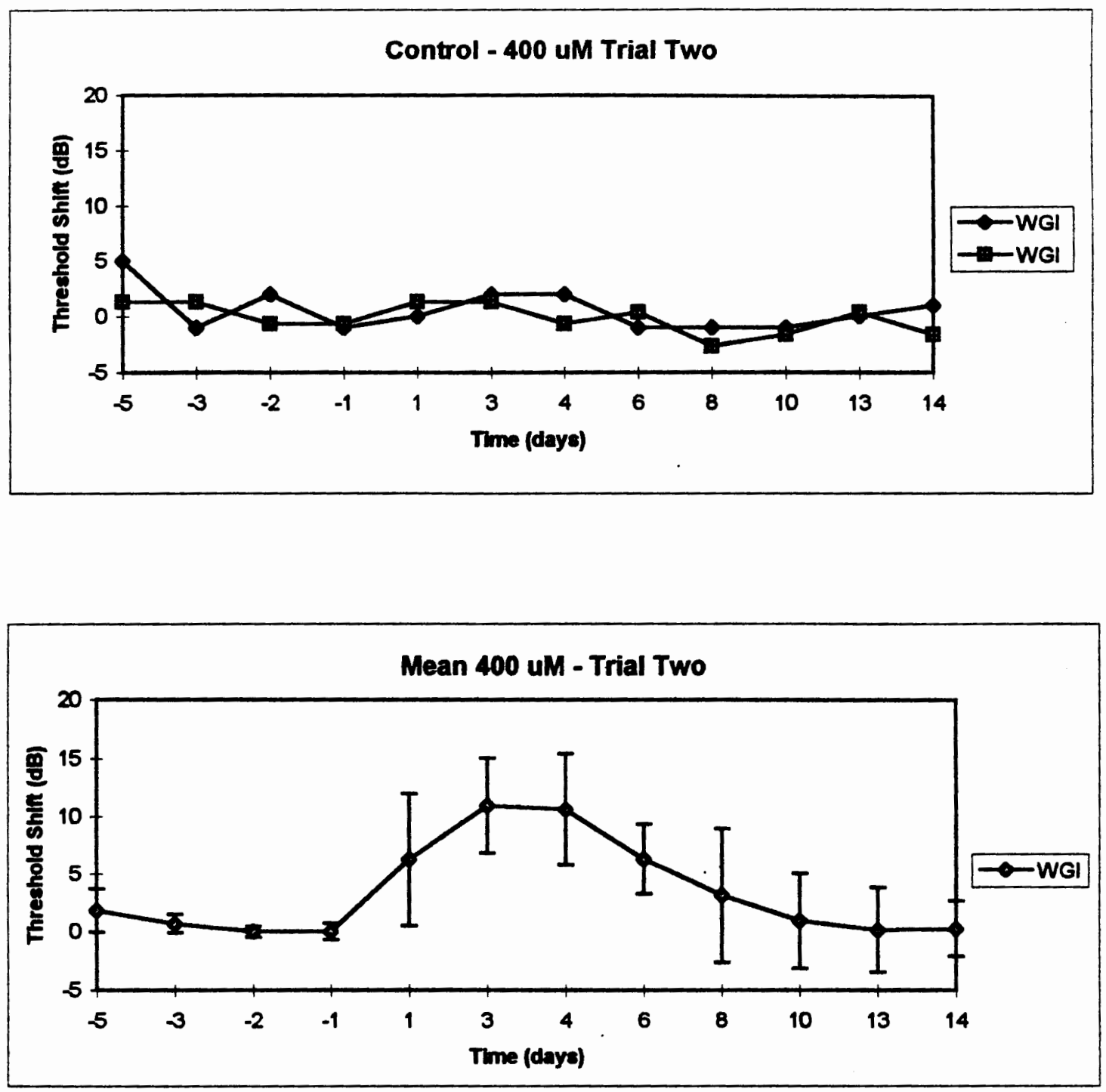

Figure 18. Top: Control group for $400 \mu \mathrm{M}$ frogs. Bottom: Trial Two threshold shift of frogs given $400 \mu \mathrm{M}$ gentamicin. (Mean \pm SD for WGI, AP, and BP clicks, $\mathrm{n}=10$ ). 


\section{Discussion}

The evoked potential or ABR technique can be used as an assay for the performance of the ascending auditory pathway. The ABR technique in frogs allows long-term recording of auditory function. I found that it is important to wait at least 24 hours following implantation of electrodes before threshold measurements are recorded. Although the animals appeared awake and active only five hours post-implant, the thresholds were found to be higher than those measured subsequently. Occasionally, even 36 hours after frogs were implanted, thresholds would be higher than normal. For this reason, thresholds were monitored for three to five days to be sure stable low thresholds were obtainable. Figure 15 and 16 (top), the $300 \mu \mathrm{M}$ control averages, demonstrate how a gradual threshold decrease occurs with time. Aminoglycosides caused presumed destruction of hair cells as early as one day post-treatment, with a maximum effect observed between three and five days. Often, total recovery is seen between 14-20 days in frogs and birds (Baird et al., 1993; Chen et al., 1993; Hashino et al., 
1991). In my study, the same time course of effect existed for the threshold shifts observed in all trials. Unfortunately, threshold recovery within the two week time period did not occur with all frogs because several frogs sickened and died. Even though Baird et al. (1993) found that bullfrogs (Rana catesbeiana) did not survive $400 \mu \mathrm{M}$ injections, I believe that an infection was to blame for the high frog mortality initially observed with Rana pipiens givien a similar dose. This is supported by the observation that a control otic puncture frog also died. In order to combat any infections that might have affected the frogs, prophylactic antibiotic (non-aminoglycosidic tetracycline) treatments were administered in later experiments. Mortality and sickness decreased markedly as seen with the second trial of $400 \mu \mathrm{M}$ frogs. In fact, the frogs showed no signs of sickness, balance problems, or lack of activity. of the trials conducted before the tetracycline treatments, frog thresholds often never reached normal threshold due to sickness and death. Vestibular toxicity due to aminoglycosidic treatment leads to behavioral changes associated with balance deficits (Honda et al., 1991; Tsue et al., 1994; Walker et al., 1990). In frogs, the observations include 
instability of the head and consequent deterioration of jumping ability. Other behaviors noted were abnormal posture and swimming (Suzuki et al., 1991). Research on rats after aminoglycosidic treatment documents vestibular deficiencies ranging from diminished swimming ability to prolonged latency for righting responses (in air) and resurfacing in water, compared to controls (Ruiz-Meza et al., 1995) .

In this study, before the prophylactic drug treatments, several frogs succumbed to a possible infection and died. Abnormal behavior such as balance problems and lack of activity was observed. However, these symptoms were not observed in the frogs that received 200 and $300 \mu \mathrm{M}$ gentamicin injections. Only the first trial of $400 \mu \mathrm{M}$ test frogs exhibited these characteristics. Frogs treated prophylactically with the tetracycline following otic puncture appeared healthy through the duration of the experiment.

As discussed earlier, this is the first research to examine the possibility of stimulating only the amphibian or basilar papillae using an AP-selective and BP-selective stimulus. From my data it is clear that substantial threshold differences between the WGI click and the AP and 
BP clicks do not exist. This similarity of sensitivity is not consistent with tuning data of Feng et al. (1975). Furthermore, there was no difference observed between the $\mathrm{AP}$ and $\mathrm{BP}$ in their response to gentamicin (Figure 13-17). There is variation among animals in the AP and particularly BP frequency range (Duellman et al., 1966; Feng and Shopner, 1981; Hetherington, 1992; Megela and Capranica, 1981). Thus, it is possible that the frequency composition of the clicks was such that they were not specific enough to evoke responses exclusively from one or the other papilla. If however, there is truly no difference in drug response by the two papillae, this suggests that any differences in AP and BP hair cells, and the organs themselves, do not confer relative protection from aminoglycoside trauma. What are the differences between the AP and BP? They both lie in their own chamber and are separated. Lewis et al. (1982) found that even though both papillae are innervated by the eighth nerve, axons in the AP connect $10-15$ hair cells while in the BP one axon innervates one hair cell. The AP hair cells are specifically tuned to frequencies in the range from $100 \mathrm{~Hz}$ to $1000 \mathrm{~Hz}$ while the BP is tuned to higher frequencies (Schmitz et al., 1992). However, it should be noted that 
the data of Schmitz et al. (1992) on characteristic frequencies were based on pure tones, not clicks. As in mammals, the AP has tonotopic organization. Even though these organs are very different in morphology, it appears the gentamicin can affect both equally. If indeed, as several studies indicate (Aran et al., 1993; Nakagawa et al., 1992; Stiffler, 1993; Tahara et al., 1995), aminoglycosides alter binding sites on plasma membranes leading to disruption of normal cell metabolism, then we can conclude that despite various physiological differences between hair cells, the membranes of all types share sufficient similarities resulting in similar aminoglycoside effects.

A further consideration is the fact that the AP and BP clicks produced ABRs with different waveform morphology. The only effect gentamicin appeared to have on the ABRs from all three clicks was a reduction of amplitude. Characteristic of a typical frog $A B R$ is four peaks. Like humans, which typically have seven peaks, the exact origin of all peaks in frogs is unknown. The reduction in amplitude of the peaks due to the gentamicin was especially pronounced in the first peak. This is to be expected since the damage is occurring at 
the hair cell level. The amplitude of peak I and subsequent reduction is clearly demonstrated in Figure 912. Recovery of the hair cells returns peak I to nearly pre-treatment amplitudes. The same phenomenon occurs to a degree with peaks II-IV.

Normally, the waveform morphology is very similar for the WGI and AP click. This is readily explained since most of the contribution to the overall evoked potential elicited by the WGI click comes from the AP, the organ with more hair cells. Typically, peaks I-IV are all present and approximately the same amplitude. However, the BP response differs in that the peaks are often less defined and have slightly smaller amplitudes. In addition, the distance between peaks, interpeak latency, can be longer with the BP waveform.

There may also be morphological differences between the actual hair cells that may determine the ototoxicity from the aminoglycoside. Baird et al. (1993) found that within the vestibular organs, hair cells in the central regions are more sensitive than hair cells in the peripheral regions. He also found that hair cells of the different auditory organs differ significantly in the hair bundle morphology in different membrane regions. Thus, it 
is possible that the number of stereovilli and the size of the kinocillium may determine a particular hair cell's susceptibility to aminoglycosides.

My data has definite correlations with current research on hair cell damage. In bullfrogs, Baird et al. (1993) found that within ten days post-injection, the cellular morphology in the gentamicin-injected animals closely resembled that seen in normal animals. In fact, he observed that the cell bodies of hair cells and supporting cells were more ordered and normal in appearance. In birds, several studies indicate that within 14 days, significant hair cell regeneration had occurred (Chen et al., 1993; Hashino et al., 1992; Weisleder and Rubel, 1993). Forge et al., (1993) report that by seven days post-gentamicin injection in guinea pigs, most of the hair cells in the striolar region were replaced completely. While these studies might support my data, it should be noted that they all involve multiple doses of aminoglycosides. Only the methodology of Baird et al. (1993) involves giving a single dose of aminoglycoside.

Research has demonstrated that some aminoglycosides affect hair cells differently, depending on their location 
within the vestibular or cochlear system (Mandell et al., 1990; Tsue et al., 1994; Wanke and Moore, 1991). The effects do not appear to be species specific. For example, hair cells in the vestibular system of humans and anurans are particularly susceptible to gentamicin (Baird et al., 1993; Smith and Swenson, 1990; Weisleder and Rubel, 1993). However, Cotanche et al. (1993) report that the avian, budgerigar, cochlear hair cells are more sensitive to gentamicin that kanamicin $160 \%$ vs. $35 \%$ damage). Hashino et al. (1992) also found that gentamicin can have a prolonged and progressively more damaging effect on hair cells for several weeks after the end of drug treatment. However, in these avian studies, the aminoglycosides were given in multiple doses over 10 days. Perhaps the damage to the hair cells depends upon the dosing schedule. Smith and Swenson (1990) report that all aminoglycosides will produce cochlear and vestibular toxicity if high concentrations are maintained in the inner ear. Certainly, aminoglycosides given over 10 days compared to one single treatment may affect the vestibular and cochlear hair cells differently. Baird et al. (1993) found that within two days treatment with $200 \mu \mathrm{M}$ gentamicin, hair cell density in the sacculus was zero and 
in the utricular striola hair cell density was about 25\% that of control bullfrogs. This supports the fact that gentamicin affects the vestibular system more than the cochlear system and by the fact that my data shows only a $20 \mathrm{~dB}$ reduction in threshold. Thus, not all cochlear hair cells were destroyed since ABRs were still produced even at gentamicin concentrations of $400 \mu \mathrm{M}$.

Perhaps, further research will yield a method with which to maximize the drug's antibiotic effects and minimize the trauma it causes the auditory system. It is also conceivable that in the future, a method to promote hair cell regeneration could be developed. Some studies have shown that vitamin $\mathrm{C}$ and proper dietary intake may reduce the ototoxic effects of aminoglycosides on the hair cells (Lautermann et al., 1995). Other research has examined the effect of growth factors on hair cell proliferation (Saffer and Corwin, 1995; Yamashita et al., 1995). Hopefully, further research will provide the answers to the exact mechanism of action of aminoglycosides on hair cells and what makes hair cells susceptible to ototoxicity. 


\section{Conclusion}

Well known for their ototoxic effects, the aminoglycosides destroy neural sensory hair cells. The injection of gentamicin into the otic capsules of Rana pipiens caused threshold shifts. In this study, hearing thresholds were measured using an $A B R$ technique. This was the first study to selectively evoke a brainstem response from the two auditory organs using computer synthesized low and high frequency clicks. A broadband sinewave click was also used. No apparent differences in threshold between the AP, BP or the sinewave click were observed. Pre- and post-gentamicin injection thresholds were measured until thresholds recovered. After the intraotic administration of gentamicin, I found the dose- and potency-dependent thresholds returned to their pretreatment thresholds within 14 days. The injection $200 \mu \mathrm{M}$ gentamicin produced threshold shifts of $10 \mathrm{~dB}$. The $300 \mu \mathrm{M}$ injections resulted in 10-15 dB threshold shifts. Injections of $400 \mu \mathrm{M}$ gentamicin yielded a threshold shift as great as $20 \mathrm{~dB}$. Recovery of threshold began between 
one and three days and total recovery occurred within 14 days post-injection for typical frogs. 


\section{Literature}

Abdouh, A., Despres, G. and Romand, R. 1993. "Hair cell overproduction in the developing mammalian cochlea in culture." Neuroreport. 5(1):33-6.

Adler, H.J., Kenealy, J.F.X., Dedio, R.M., and Saunders, J.C. 1992. "Threshold Shift, Hair Cell Loss, and Hair Bundle Stiffness Following Exposure to 120 and $125 \mathrm{~dB}$ Pure Tones in the Neonatal Chick." Acta. otolaryngol. Stockholm. 112:444-454.

Ahida, K. 1992. "Comparison of vulnerability between avian and mammalian inner ears - electrophysiolgical and morphological studies." Nippon Jibiinkoka. Gakkai. Kaiho. 95:1968-80.

Alles, R.M. and Pye, A. 1993. "Cochlear damage in guinea pigs following contralateral sound stimulation with and without gentamicin." Br. J. Audiol. 27(3):18393.

Ankerstjerne, J.K., Cass, S.P., Scudder, C.A. and Nissim, K.R. "Gentamicin sensitivity of Vestibular Nerve fibers." Abstract of the Eighteenth Midwinter Research Meeting, Association for Research in otolaryngology.

Aran, J.M., Dulon, D., Hiel, H., Erre, J.P. and Aurousseau, C. 1993. "Ototoxicity of aminoglycosides: recent results on uptake and clearance of gentamicin by sensory cells of the cochlea." Rev. Laryngol. Otol. Rhinol. Bord. $114(2): 125-8$.

Arritola, T. 1995. Drug Handbook. Springhouse Corporation. Philadelphia.

Baird, R.A., Torres, M.A., and Schuff, N.R. 1993. "Hair cell regeneration in the bullfrog vestibular otolith organs following aminoglycoside toxicity." Hear.

Res. 65:164-74. 
Canlon, B., Borg, E. and Flock, A. 1988. "Protection against noise trauma by pre-exposure to a low level acoustic stimulus." Hear. Res. 34:197-200.

Carey, M.B. and Zelick, R. 1993. "The effect of sound level, temperature and dehydration on the brainstem auditory evoked potential in anuran amphibians." Hear. Res. 70:216-228.

Cecola, R.P. and Bobbin, R.P. 1992. "Lowering extracellular chloride concentration alters outer hair cell shape." Hear. Res. 61:65-72.

Chen, L., Salvi, R.J. and Hashino, E. 1993. "Recovery of CAP threshold and amplitude in chickens following kanamycin ototoxicity." Hear. Res. 69:15-24.

Cheung, R., Clark, P., Nicholson, P.W., Deshmukh, A.A., O'Neill, C.J., Dobbs, S.M. and Dobbs, R.J. 1990. "Screening for aminoglycoside auditory toxicity in the old." Br. J. Clin. Pharmacol. 30(1):1-11.

Clerici, W. J., Hensley, K., DiMartino, D.L. and Butterfield, D.A. 1995. "Direct determination of reactive oxygen species generation by ototoxicants using electron paramagnetic resonance." Abstract of the Eighteenth Midwinter Research Meeting, Association for Research in Otolaryngology.

Corwin, J.T., Jones, J.E., Katayama, A., Kelley, M.W. and Warchol, M.E. 1991. "Hair cell regeneration: The identities of progenitor cells, potential triggers and instructive cues." Ciba Found. Symp. 160:103-20

Corwin, J.T. and Warchol, M.E. 1991. "Auditory Hair Cells: Structure, Function, Development, and Regeneration." Ann. Rev. Neurosci. 14:301-33.

Corwin, J.T., Warchol, M.E. and Kelley, M.W. 1993. "Hair cell developement." Curr. Opin. Neurobiol. $3(1): 32-7$.

Cotanche, D.A., Lee, K.H., Stone, J.S. and Picard,D. 1994. "Regeneration of hair cells in the vestibulocochlear system of birds and mammals." Curr. Opin. Neurobiol. 4(4):509-14. 
Denk, W., Leolian, R.M. and Webb, W.W. 1992. "Mechanical response of frog saccuar hair bundles to the aminoglycoside block of mechanoelectrical transduction." J. Neurophysiol. 68:927-32.

Duckert, L.G. and Rubel, E.W. 1993a. "Current concepts in hair cell regeneration." Otolaryngol. Clin. North Am. 26(5):873-901.

Duckert, L.G. and Rubel, E.W. 1993b. "Morphological Correlates of Functional Recovery in the Chicken Inner Ear After Gentamycin Treatment." J. Comp. Neurol. 331:75-96.

Duellman, W.E. 1966. "Social Organizations $\mathrm{n}$ the mating calls of some neotropical anurans." Amer. Midland Natur. $77: 156-163$.

Duff, P. 1992. "The aminoglycosides." Obstet. Gynecol. Clin. North Am. 19:511-7.

Epstein, J.E. and Cotanche, D.A. 1995. "High doses of gentamicin fail to induce tectorial membrane damage in chick cochlea." Abstract of the Eighteenth Midwinter Research Meeting, Association for Research in Otolaryngology.

Ernst, A. and Zenner, H.P. 1992. "Clinical applications and importance of selected, modern results of hearing research." Wien. Medical. Wochenshr. 142:450-4.

Fausti, S.A., Frey, R.H., Henry, J.A., Olson, D.J. and Schaffer, H.I. 1992. "Early detection of ototoxicity using high-frequency, tone-burst-evoked auditory brainstem responses." J. Amer. Acad. Audiol. 3: 397-404.

Feng, A.S., Narins, P.M. and Capranica, R.R. 1975. "Three populations of primary auditory fibres in the bullfrog (Rana Catesbeiana): their peripheral origins and frequency selectivity." J. Comp. Physiol. $100: 221-9$.

Feng, A.S., and Shofner, W.P. 1981. "Peripheral basis of sound localization in anuran, acoustic properties of the frog's ear." Hear. Res. 5:201-216.

Flock, A. and Flock, B. 1966. "Ultrastructure of the amphibian papilla in the bullfrog." J. Comp. Physiol. 100:221-229. 
Eorge, A., Li, I., Corwin, J.T. and Nevill, G. 1993. "Ultrastructural Evidence for Hair Cell Regeneration in the Mammalian Inner Ear." Science. 259:16161619 .

Girod, D.A. and Rubel, E.W. 1991. "Hair cell regeneration in the avian cochlea: if it works in birds, why not in man?" Ear Nose Throat $J$. $70(6): 343-50,353-4$.

Harada, N., Ernst, A. and Zenner, H.P. 1994. "Intracellular calcium changes by hyposmotic activation of cochlear outer hair cells in the guinea pig." Acta. Otolaryngol. Stockholm. 114(5):510-5

Hashino, E., Tanaka, Y., Salvi, R. and Sokabe, M. 1992. "Hair cell regeneration in the adult budgerigar after kanamycin ototoxicity." Hear. Res. 59:46-58.

Hernandez, J., Hoffman, I. and Honrubia, V. 1995. "Functional characterization of regenerated canicular primary afferents in Rana Catesbeiana." Abstract of the Eighteenth Midwinter Research Meeting, Association for Research in Otolaryngology.

Hetherington, T.E. 1992. "The effects of body size on functional properties of middle ear systems of anuran amphibians." Brain Behav. Evol. 39(3):133-42.

Hiel, H., Erre, J.P., Aurousseau, C., Bouali, R., Dulon, D. and Aran, J.M. 1993. "Gentamicin uptake by cochlear hair cells precedes hearing impairment during chronic treatment." Audiology. 32(1):78-87.

Hillery, C.M. and Narins, P.M. 1984. "Neurophysiologic evidence for a traveling wave in the amphibian inner ear." Science. 225:1037-1039.

Honda, N., Saito, H., Aoyama, H. and Nojyo, Y. 1991. "An in vitro rapid evaluation of drug-induced ototoxicity and of reductive effect of calcium on aminoglycoside ototoxicity using organ cultures." Nippon Jibiinkoka. Gakkai. Kaiho. 94(8):1084-97.

Imamura, S. and Adams, J.C. 1995. "Distribution and effects of gentamicin in the guinea pig inner ear." Abstract of the Eighteenth Midwinter Research Meeting, Association for Research in Otolaryngology. 
Kelley, M.W., Ochiai, C.K. and Corwin, J.T. 1992. "Maturation of kinocilia in amphibian hair cells: growth and shortening related to kinociliary bulb formation." Hear. Res. 59(1):108-15.

Kelley, M.W., Xu, X.M., Wagner, M.A., Warchol, M.E. and Corwin, J.T. 1993. "The developing organ of Corti contains retinoic acid and forms supernumerary hair cells in response to exogenous retinoic acid in culture." Development. 119(4):1041-53.

Kroese, A.B.A. and Bercken, J.V.D. 1982. "Effects of ototoxic antibiotics on sensory hair cell functioning." Hear. Res. 6:183-197.

Kroese, A.B.A., Das, A. and Hudspeth, A.J. 1989. "Blockage of the transduction channels of hair cells in the bullfrog's sacculus by aminoglycoside antibiotics." Hear. Res. 37:203-218.

Lautermann, J., McLaren, J. and Schacht, J. 1995. "Correlation between expression of gentamicin ototoxicity and inner ear glutathione levels." Abstract of the Eighteenth Midwinter Research Meeting, Association for Research in Otolaryngology.

Lefebvre, P.P., Malgrange, B. Staecker, H. Moonen, G. and Van De Water, T.R. 1993. "Retinoic Acid Stimulates Regeneration of Mammalian Auditory Hair Cells." Science. 260:692-695.

Lewis, E.R., Leverenz, E.I. and Koyama, H. 1982. "The tonotopic organization of the bullfrog amphibian papilla, an auditory organ lacking a basilar membrane." J. Comp. Physiol. 145:437-445.

Lewis, E.R., Hecht, E.I. and Narins, P.M. 1992. "Diversity of form in the amphibian papilla of Puerto Rican forgs." J. Comp. Physiol. 171(4):421-35.

Li, S., Zhu, H. and Zhang, Q. 1994. "Hair cell regeneration and recovery following gentamicin induced damage in the chick cochlea." Chung. Hua. Erh. Pi. Yen. Hou. Ko. Tsa. Chih. 29(2):89-91.

Lippe, W.R., Westbrook, E.W., and Ryals, B.M. 1991. "Hair cell regeneration in the chicken cochlea following animoglycosidic toxicity." Hear. Res. 56:203-210. 
Lippe, W.R., Hathaway, O. and Parlotz, D. 1995. "Loss of avian spiral ganglion neurons following aminoglycoside-induced hair cell loss and regeneration." Abstract of the Eighteenth Midwinter Research Meeting, Association for Research in otolaryngology.

Lomax, M.I., Hegeman, A.D., Gong, T.W., Adler, H.J. and Raphael, Y. 1995. "Identification of genes activated by acoustic trauma in the chick auditory tectum." Abstract of the Eighteenth Midwinter Research Meeting, Association for Research in otolaryngology.

Lombarte, A., Hong, Y.Y., Popper, A.N., Chang, J.S. and Platt, C. 1993. "Damage and regeneration of hair cell ciliary bundles in a fish ear following treatment with gentamicin." Hear. Res. 64:166-74.

Lou, W., Dong, M. and Dong, M. 1994. "Hair cell damage and regeneration in the quail cochlea following knamycin ototoxicity." Chung.-Hua-Erh Pi Yen Hou KoTsa-Chih. 29(2):85-8.

Ma, C.L. 1990. "Cisplatin cochlear toxicity." Chung. Hua. Erh. Pi. Yen. Hou. Ko. Tsa. Chih. 25(4):205-7, 254 .

Mandell, G.I., Douglas, G.R. and Bennett, J.E. 1990. "Aminoglycosides." Principles and Practice of Infectious Diseases. Churchill Livingston. New York.

Megela, A.L. and Capranica, R.R. 1981. "Response patterns to tone bursts in periphery auditory systems of anurans." J. Neurophysiol. 46(3):465-478.

Meiteles, L.Z. and Raphael, Y. 1994. "Scar formation in the vestibular sensory epithelium after aminoglycoside toxicity." Hear. Res. 79(1-2):26-38.

Meza-Ruiz, G., Bohne, B.A., Daunton, N., Fox, R. LopezGriego, L., Zepeda, H. and Carrillo, P. 1995. "Injury and recovery in the rat's vestibular system following streptomycin treatment: A behavioral and anatomical study." Abstract of the Eighteenth Midwinter Research Meeting, Association for Research in otolaryngology. 
Nakagawa, T., Kakehata, S., Akaike, N., Komune, S., Takasaka, T. and Uemura, T. 1992. "Effects of $\mathrm{Ca}+2$ antagonists and aminoglycoside antibiotics on $\mathrm{Ca}+2$ current in isolated outer hair cells of guinea pig cochlea." Brain Res. 580(1-2):345-7.

Niemiec, A.J., Raphael, Y. and Moody, D.B. 1995. "Behavoral measures of the return of auditory function following two pure tone exposures." Abstract of the Eighteenth Midwinter Research Meeting, Association for Research in Otolaryngology.

Northcutt, R.G. and Ronan, M. 1992. "Afferent and efferent connections of the bullfrog medial pallium." Brain Behav. Evol. $40(1): 1-16$.

Oesterle, E.C. and Rubel, E.W. 1993. "Postnatal production of supporting cells in the chick cochlea." Hear. Res. 66:213-124.

Plinkert, P.K., Plinkert, B. and Zenner, H.P. 1992. "Carbohydrates in the cell surface of hair cells from the guinea pig cochlea." Eur. Arch. otorhinolaryngol. 249(2):67-73.

Presson, J.C., Mentz, C. and Popper, A.N. 1995. "Recycling of hair cell precursors in the ear of a postembryonic fish." Abstract of the Eighteenth Midwinter Research Meeting, Association for Research in Otolaryngology.

Priuska, E.M. and Schacht, J. 1995. "The radical activities of gentamicin." Abstract of the Eighteenth Midwinter Research Meeting, Association for Research in otolaryngology.

Pugliano, F.A., Pribitikin, E., Adler, H.J. and Saunders, J.C. 1993a. "Growth of Evoked Potential Amplitude in Neonatal Chicks Exposed to Intense Sound." Acta. otolaryngol. Stockholm. 113:18-25.

Pugliano, F.A., Wilcox, T.O., Rossiter, J. and Saunders, J.C. 1993b. "Recovery of auditory structure and function in neonatal chicks exposed to intense sound for 8 days." Neurosci. Lett. 151:214-8.

Pye, A. and Collins, P. 1991. "Interaction between sound and gentamicin: Immediate threshold and stereociliary changes." Br. J. Audiol. $25(6): 381-$ 90 . 
Quint, E., Hackney, C.M. and Furness, D.N. 1995. "The effect of neomycin on the utricular epithelium of the adult guinea pig in vitro." Abstract of the Eighteenth Midwinter Research Meeting, Association for Research in Otolaryngology.

Raphael, Y. 1993. "Reorganization of the Chick Basilar Papilla After Acoustic Trauma." J. Comp. Neurol. $330: 521-532$.

Rubel, E.W., Oesterle, E.C. and Weisleder, P. 1991. "Hair cell generation in the avian inner ear." Ciba Found. Symp. 160:77-96.

Saffer, L.D. and Corwin, J.T. 1995. "RT-PCR assessment of mRNAs for growth factor receptors expressed in control and neomycin-damaged utricular sensory epithelia from rats." Abstract of the Eighteenth Midwinter Research Meeting, Association for Research in otolaryngology.

Salonna, I., Bartoli, R. and Quaranta, A. 1992. "Brainstem auditory pathways: effects of atropine." Boll. Soc. Ital. Biol. Sper. 69:209-16.

Saunders, J.C., Torsiglieri, A.J. and DeDio, R.M. 1993. "The growth of hearing loss in neonatal chicks exposed to intense pure tones." Hear. Res. 69:2534 .

Schmitz, B., White, T.D. and Narins, P.M. 1992. "Directionality of phase locking in auditory nerve fibres of the leopard frog Rana pipiens pipiens." J. Comp. Physiol. 170:589-604.

Seaman, R.L. 1991. "Method to record evoked potentials from the frog eighth nerve." Hear. Res. 51:301-306.

Shrimpton, S.B., Milmoe, M., Wilson, A.P., Felmingham, D., Drayan, S., Barrass, C., Gruneberg, R.N. and Ridgway, G.L. 1993. "Audit of prescription and assay of aminoglycosides in a UK teaching hospital." $\mathrm{J}$. Antimicrob. Chemother. 31:599-606.

Simmons, D.D., Bertolotto, C. and Narins, P.M. 1992. "Innervation of the amphibian and basilar papilla in the leopard frog: reconstructions of single labled fibers." J. Comp. Neurol. 322(2):191-200. 
Slepecky, N.B. and Ulfendahl, M. 1993. "Evidence for calcium-binding proteins and calcium-dependent regulatory proteins in sensory cells of the organ of Corti." Hear. Res. 70(1):73-84.

Smith, G.H. and Swenson, C. 1990. "Aminoglycoside Ototoxicity." Micromedex Drug Information Consults. University of Washington. 79:1946.

Sobkowicz, H.M. and Slapnick, S.M. 1994. "The efferents interconnecting auditory inner hair cells." Hear.

Res. $75(1-2): 81-92$.

Stiffler, D.F. 1993. "Amphibian calcium metabolism." J. Exp. Biol. 184:47-61.

Stone, J.S. and Cotanche, D.A. 1992. "Synchronization of hair cell regeneration in the chick cochlea following noise damage." J. Cell SCi. 102:671-680.

Stone, J.S., Kelley, M.W. and Rubel, E.W. 1995. "Support cell proliferation and hair cell differentiation in aminoglycoside-treated explants of the mature chick cochlear epithelium." Abstract of the Eighteenth Midwinter Research Meeting, Association for Research in Otolaryngology.

Suzuki, M., Omura, R., Hamamura, N., Hirakawa, H., Kawaguchi, K. and Harada, Y. 1991. "Effect of gentamicin intoxication on frog behavior." Acta. Otolaryngol. Suppl. - Stockholm. 481:77-9.

Tahara, T., Yamashita, H. and Takahashi, M. "Streptomycin sulfate induces transient reduction of $\mathrm{S}-100$ protein in the vestibular ganglia and nerve." Abstract of the Eighteenth Midwinter Research Meeting, Association for Research in Otolaryngology.

Tilney, L.G., Contanche, D.A. and Tilney, M.S. 1992. "Actin filaments, stereocilia and hair cells of the bird cochlea - How the number and arrangement of stereocilia are determined." Development. $116: 213-26$.

Trautwein, P.G., Chen, L., Salvi, R.J. and Shero, M. 1995. "CAP threshold and amplitude recovery in chickens following acoustic trauma." Abstract of the Eighteenth Midwinter Research Meeting, Association for Research in otolaryngology. 
Tsue, T.T., Watling, D.L., Weisleder, P., Coltrera, M.D. and Rubel, E.W. 1994. "Identification of hair cell progenitors and intermitotic migration of their nuclei in the normal and regenerating avian inner ear." J. Neurosci. 14(1):140:52.

Umemoto, M., Sakagami, M., Ashida, K., Fukazawa, K., Matsunaga, T. and Senda T. 1993. "Regeneration of adult budgerigar's hair cells following acoustic trauma." ORL. J. Otorhinolaryngol. Relat. Spec. $55(6): 325-31$.

Walker, E.M., Fazekes-May, M.A. and Bowen, W.R. 1990. "Nephrotoxic and ototoxic agents." Clin. Lab. Med. $10(2): 323-54$.

Wanke, L.A. and Moore, R.L. 1991. Drug-Induced Hearing Disorders." Micromedex Drug Information Consults. University of Washington. 79:7745.

Warchol, M.E., Lambert, P.R., Goldstein, B.J., Forge, A. and Corwin, J.T. 1993. "Regenerative proliferation in inner ear sensory epithelia from adult guinea pigs and humans." Science. 259:1619-22.

Weisleder, P. and Rubel, E.W. 1993. "Hair Cell Regeneration After Streptomycin Toxicity in the Avian Vestibular Epithelium." J. Comp. Neurol. 331:97110 .

Weisleder, P. and Zakon, H.H. 1995. "Regeneration of tuberous electroreceptor organs in nerveless skin of a weakly electric fish." Abstract of the Eighteenth Midwinter Research Meeting, Association for Research in Otolaryngology.

Wilczynski, W. and Capranica, R.R.. 1984. "The auditory system of Anuran Amphibians." Progress in Neurobiology. 22:1-38.

Yamashita, H., Tahara, T. and Takahashi, M. 1995. "Transtypanic injection of TGF-alpha induces supporting cell proliferation of mice utricles." Abstract of the Eighteenth Midwinter Research Meeting, Association for Research in Otolaryngology. 


\section{Appendix}

\section{Concentration Calculations}

\section{$200 \mu \mathrm{M}$ Concentration:}

$$
\begin{aligned}
\left([\text { con }]_{\text {initial }}\right)\left(V o l_{\text {initial }}\right) & =\left([\text { con }]_{\text {final }}\right)\left(V_{0} l_{\text {final }}\right) \\
\left([\text { con }]_{\text {initial }}\right) & (4 \mu l)=(200 \mu \mathrm{M})(15 \mu l) \\
\left([\text { con }]_{\text {initial }}\right) & =750 \mu \mathrm{M}
\end{aligned}
$$

$300 \mu \mathrm{M}$ Concentration:

$$
\begin{aligned}
\left([\mathrm{con}]_{\text {initial }}\right)\left(\mathrm{Vol}_{\text {initial }}\right) & =\left([\mathrm{con}]_{\text {final }}\right)\left(\mathrm{Vol}_{\text {final }}\right) \\
\left([\mathrm{con}]_{\text {initial }}\right)(4 \mu \mathrm{l}) & =(300 \mu \mathrm{M})(15 \mu \mathrm{l}) \\
\left([\mathrm{con}]_{\text {initial }}\right) & =1125 \mu \mathrm{M}
\end{aligned}
$$

\section{$400 \mu \mathrm{M}$ Concentration:}

$$
\begin{aligned}
\left([\text { con }]_{\text {initial }}\right)\left(V o l_{\text {initial }}\right) & =\left([\text { con }]_{\text {final }}\right)\left(\operatorname{Vol}_{\text {final }}\right) \\
\left([\text { con }]_{\text {initial }}\right) & (4 \mu l)=(400 \mu \mathrm{M})(15 \mu l) \\
\left([\text { con }]_{\text {initial }}\right) & =1500 \mu \mathrm{M}
\end{aligned}
$$

\section{Sample calculation for $400 \mu \mathrm{M}$ GS concentration:}

1. We want $1500 \mu \mathrm{M}=10^{-6}$ moles and $1500 \mu \mathrm{M}=.0015$ moles

2. We also want to make $10 \mathrm{ml}$ of solution $(0.010 \mathrm{I})$ so, how many moles do we need to make a 0.0015 molar solution? (molar $=\mathrm{mol} / \mathrm{L}$ )

3. $(.010 \mathrm{I}) \times(.0015 \mathrm{~mol} / 1.0 \mathrm{I})=0.000015$ moles $\mathrm{GS}$

4. Now, how many grams in 0.000015 moles?

5. $\mathrm{MW}$ of $\mathrm{GS}=464 \mathrm{grams} / \mathrm{mole}$

6. $(.000015$ moles GS) $\times(464 \mathrm{~g} / \mathrm{mol} \mathrm{GS})=.00696 \mathrm{~g}=6.96 \mathrm{mg}$

7. However, the GS is only $652 \mu \mathrm{g}$ gentamicin base per $\mathrm{mg}$.

8. Thus, we divide $6.96 \mathrm{mg}$ by .652 to yield $10.67 \mathrm{mg}$.

9. Thus, we add $10.67 \mathrm{mg}$ of GS to $10 \mathrm{ml}$ of HEPES-buffered saline solution. 